\title{
中国毛竹林碳氮磷生态化学计量特征
}

\author{
杜满义 ${ }^{1,2,3}$ 范少辉 $1,2^{*}$ 刘广路 ${ }^{1,2 *}$ 封焕英 ${ }^{1,2,3}$ 郭宝华 1,2 唐晓鹿 1,2
}

${ }^{1}$ 国际竹藤中心, 北京 $100102{ }^{2}{ }^{2}$ 国家林业局竹藤科学与技术重点实验室, 北京 $100102 ;^{3}$ 中国林业科学研究院华北林业实验中心, 北京 102300

摘 要 碳 $(\mathrm{C})$ 、氮 $(\mathrm{N})$ 、磷 $(\mathrm{P})$ 生态化学计量比是生态系统过程与功能的重要特征, 开展种群生态化学计量学研究可以细化植 物种群化学计量学内容, 确定限制植物生长的元素类型, 同时为大尺度模型的发展提供数据基础。为阐明我国毛竹 (Phyllostachys edulis) 林C、N、P化学计量学特征, 通过对毛竹主要产区文献数据的搜集整理与分析, 探索我国毛竹林“植物土壤-调落物”系统C、N、P及 $\mathrm{N}: \mathrm{N} 、 \mathrm{C}: \mathrm{P} 、 \mathrm{~N}: \mathrm{P}$ 生态化学计量特征，以及不同组分生态化学计量特征与经纬度之间的关系。结 果表明: 1) 我国毛竹林叶片 $\mathrm{C}$ 含量为 $478.30 \mathrm{mg} \cdot \mathrm{g}^{-1}, \mathrm{~N}$ 含量为 $22.20 \mathrm{mg} \cdot \mathrm{g}^{-1}, \mathrm{P}$ 含量为 $1.90 \mathrm{mg} \cdot \mathrm{g}^{-1}, \mathrm{C}: \mathrm{N}$ 为 $26.80, \mathrm{C}: \mathrm{P}$ 为 $299.60, \mathrm{~N}: \mathrm{P}$ 为 14.40; 毛竹林 $0-20 \mathrm{~cm}$ 土层 $\mathrm{C}$ 含量为 $21.53 \mathrm{mg} \cdot \mathrm{g}^{-1}, \mathrm{~N}$ 含量为 $1.66 \mathrm{mg} \cdot \mathrm{g}^{-1}, \mathrm{P}$ 含量 $0.41 \mathrm{mg} \cdot \mathrm{g}^{-1}, \mathrm{C}: \mathrm{N}$ 为 $14.20, \mathrm{C}: \mathrm{P}$ 为 $66.74, \mathrm{~N}: \mathrm{P}$ 为 4.28 ; 毛竹调落物 $\mathrm{C}$ 含量为 $438.49 \mathrm{mg} \cdot \mathrm{g}^{-1}, \mathrm{~N}$ 含量为 $13.39 \mathrm{mg} \cdot \mathrm{g}^{-1}, \mathrm{P}$ 含量为 $0.86 \mathrm{mg} \cdot \mathrm{g}^{-1}, \mathrm{C}: \mathrm{N}$ 为 $22.53, \mathrm{C}: \mathrm{P}$ 为 $665.67, \mathrm{~N}: \mathrm{P}$ 为 22.55 。2)毛竹林 “植物-土壤-凋落物”系统中, $\mathrm{C}: \mathrm{N}$ 表现为: 叶片 $>$ 调落物 $>$ 土壤, $\mathrm{C}: \mathrm{P}$ 和 $\mathrm{N}: \mathrm{P}$ 均表现为: 调落物 $>$ 叶片 $>$ 土壤, 叶片 $\mathrm{N} 、 \mathrm{P}$ 再吸收率分 别为 $39.68 \%$ 和 $54.74 \%$, 我国毛竹林生长发育总体上可能受到 $\mathrm{P}$ 限制或者 $\mathrm{N}$ 和P两种元素的双重限制。3)纬度梯度: 叶片 $\mathrm{N}$ 含量、 $\mathrm{N}: \mathrm{P}$ 随纬度增加而增加, C:N随纬度增加而降低。经度梯度: 叶片 $\mathrm{N}: \mathrm{P}$ 随经度增加而增加, $\mathrm{P}$ 含量、 C:N随经度增加而降低; 土壤 $\mathrm{C}: \mathrm{N}$ 随经度增加而增加, $\mathrm{N}$ 含量随经度增加而降低; 调落物 $\mathrm{N}$ 含量随经度增加而降低。4)叶片 $\mathrm{N}$ 含量与年平均气温和年降水量均 存在明显负相关关系, 但对温度的响应比降水更敏感, 叶片 $\mathrm{N}$ 含量与纬度呈正相关关系, 支持“温度-植物生理假说”, 反映了 植物对自然环境的适应。

关键词 叶片; 土壤; 调落物; 纬度; 经度; 生态化学计量

引用格式: 杜满义, 范少辉, 刘广路, 封焕英, 郭宝华, 唐晓鹿 (2016). 中国毛竹林碳氮磷生态化学计量特征. 植物生态学报, 40, 760-774. doi: $10.17521 /$ cjpe.2015.0464

\section{Stoichiometric characteristics of carbon, nitrogen and phosphorus in Phyllostachys edulis for- ests of China}

DU Man-Yi ${ }^{1,2,3}$, FAN Shao-Hui ${ }^{1,2 *}$, LIU Guang-Lu ${ }^{1,2^{*}}$, FENG Huan-Ying ${ }^{1,2,3}$, GUO Bao-Hua ${ }^{1,2^{*}}$, and TANG Xiao-Lu ${ }^{1,2}$

${ }^{1}$ International Centre for Bamboo and Rattan, Beijing 100102, China; ${ }^{2}$ Key Laboratory of Science and Technology of Bamboo and Rattan, State Forestry Administration, Beijing 100102, China; and ${ }^{3}$ North China Foresty Experiment Center, Chinese Academy of Forestry, Beijing 102300, China

\section{Abstract}

Aims Stoichiometric ratios of carbon (C), nitrogen (N) and phosphorus (P) are important characteristics of the ecological processes and functions. Studies on population ecological stoichiometry can refine the content of flora chemometrics, determine the limited nutrient, and provide data for process-based modeling over large scale. Phyllostachys edulis is an important forest type, whose area accounts for $74 \%$ of total bamboo forest area in Southern China. However, little is known about the ecological stoichiometric in P. edulis. This study aimed to reveal C:N, C:P and N:P stoichiometry characteristics of the "plant-soil-litter" continuum and to provide a better understanding nutrient cycling and stability mechanisms in $P$. edulis forest in China.

Methods The data were collected from the published literature containing C、N、P content in leaf or surface soil $(0-20 \mathrm{~cm})$ or littefall in $P$. edulis forests.

Important findings 1) The leaf $\mathrm{C}, \mathrm{N}, \mathrm{P}$ content were estimated at $478.30 \mathrm{mg} \cdot \mathrm{g}^{-1}, 22.20 \mathrm{mg} \cdot \mathrm{g}^{-1}, 1.90 \mathrm{mg} \cdot \mathrm{g}^{-1}$ in $P$. edulis, and the corresponding C: N, C: P and N: P were 26.80, 299.60 and 14.40, respectively. Soil C, N, and P content in $0-20 \mathrm{~cm}$ were $21.53 \mathrm{mg} \cdot \mathrm{g}^{-1}, 1.66 \mathrm{mg} \cdot \mathrm{g}^{-1}, 0.41 \mathrm{mg} \cdot \mathrm{g}^{-1}$, with ratios of $14.20 \mathrm{for} \mathrm{C}: \mathrm{N}, 66.74$ for $\mathrm{C}: \mathrm{P}$ and 4.28 for $\mathrm{N}: \mathrm{P}$. The $\mathrm{C}, \mathrm{N}$ and $\mathrm{P}$ contents were $438.49 \mathrm{mg} \cdot \mathrm{g}^{-1}, 13.39 \mathrm{mg} \cdot \mathrm{g}^{-1}, 0.86 \mathrm{mg} \cdot \mathrm{g}^{-1}$ for litterfall, with the litter C:N, C:P and N:P being 25.53, 665.67, 22.55, respectively. 2) In the plant-soil-litter system in P. edulis forest, leaf had higher C:N, litter had higher C:P and N:P, while soil were the lowest. The N, P resorption rate was 39.68\%

收稿日期Received: 2015-12-17 接受日期Accepted: 2016-04-23

* 共同通信作者Co-author for correspondence (E-mail: fansh@icbr.ac.cn; liuguanglu@icbr.ac.cn) 
and $54.74 \%$, indicating that $P$. edulis forest growth and development was constrained by $\mathrm{P}$ or by both of $\mathrm{N}$ and $\mathrm{P}$ in China. 3) $\mathrm{N}$ content and $\mathrm{N}: \mathrm{P}$ in leaf showed a tendency to increase with latitude, while the C:N of leaf declined with latitude. $\mathrm{N}: \mathrm{P}$ of leaf increased with longitude, but the $\mathrm{P}$ content and the $\mathrm{C}: \mathrm{N}$ of leaf showed a opposite trend. $\mathrm{C}$ : $\mathrm{N}$ of soil increased with longitude, whereas the $\mathrm{N}$ content of soil declined longitude. The $\mathrm{N}$ content of litter declined with longitude. 4) The leaf $\mathrm{N}$ content was negatively correlated with mean annual temperature and mean annual precipitation, but being more sensitive to temperature than precipitation. The positive correlations between $\mathrm{N}$ content and latitude support "Temperature-Plant Physiological" hypothesis, reflecting an adaptive strategy to environmental conditions.

Key words leaf; soil; litterfall; latitude; longitude; ecological stoichiometry

Citation: Du MY, Fan SH, Liu GL, Feng HY, Guo BH, Tang XL (2016). Stoichiometric characteristics of carbon, nitrogen and phosphorus in Phyllostachys edulis forests of China. Chinese Journal of Plant Ecology, 40, 760-774. doi: 10.17521/cjpe.2015.0464

生态化学计量学为研究生态系统能量和化学元 素(主要是碳 $(\mathrm{C})$ 、氮 $(\mathrm{N})$ 和磷 $(\mathrm{P})$ 等)平衡以及生态系 统结构与功能提供了一种新的手段 (Elser et al., 2000a, 2000b; 贺金生和韩兴国, 2010)，探讨C、N、 $\mathrm{P}$ 的计量关系是研究有机体的特性及行为与生态系 统间相互关系的有效途径(Zhang et al., 2003)。目前, $\mathrm{C}: \mathrm{N}: \mathrm{P}$ 化学计量学特征广泛应用于植物功能群落及 多样性(Tessier \& Raynal, 2003; Vitousek., 2003)、限 制性元素判断 (Agren, 2004)、调落物分解 (Mooshammer et al., 2012) 以及植物对环境变化的适 应能力(Dijkstra et al., 2012; 牛得草等, 2013)等多个 领域, 而对森林生态系统化学计量整体性的研究缺 乏, 阻碍了对化学计量“内稳态理论”和化学利用效 率的进一步理解。竹子是我国森林资源重要的组成 部分, 中国有竹类植物 35 属, 近 400 种 (江泽慧, 2002), 其中毛竹(Phyllostachys edulis)经济效益与生 态功能俱佳, 是我国种植面积最大、分布范围最广、 培育历史最悠久的竹种。第八次森林资源清查报告 结果(国家林业局, 2014)显示, 目前我国毛竹林面积 443 万 $\mathrm{hm}^{2}$, 占全国竹林面积的 $74 \%$ 。开展毛竹林相 关生态化学计量学研究可以细化植物种群化学计量 学内容, 提供土壤营养诊断依据, 同时也为实现大 尺度下生态系统化学计量学研究和转化提供参考 (顾大形等, 2011)。目前毛竹林有关养分元素的研究 主要集中于林分尺度下养分元素的丰缺以及养分分 布和循环特征等方面, 对区域或国家尺度上毛竹林 C、N、P化学计量特征的研究比较薄弱(郭宝华, 2014; 郭宝华等, 2014), 同时对植物-土壤-调落物 C、N和P营养元素传递与调节机理的研究还比较缺 乏, 应把植物与土壤作为一个整体进行更深入、多 层次的生态化学计量研究(洪江涛等, 2013)。为探索
我国毛竹林C、N、P化学计量学特征，在搜集国内 外相关参考文献的基础上，利用已发表的相关论文 数据, 经过汇总、分析, 阐明我国毛竹林叶片、土壤 及调落物 $\mathrm{C} 、 \mathrm{~N} 、 \mathrm{P}$ 及 $\mathrm{C}: \mathrm{N} 、 \mathrm{C}: \mathrm{P} 、 \mathrm{~N}: \mathrm{P} 、 \mathrm{C}: \mathrm{N}: \mathrm{P}$ 生态化 学计量特征, 揭示毛竹林生态系统中植物植被-调 落物-土壤C、N、P营养元素的传递机制和调节机理, 并判断我国毛竹林的限制性元素, 为科学经营毛竹 林提供新的理论依据和方法, 也为实现降低毛竹林 地肥料的大量使用提供可靠数据。

\section{1 材料和方法}

\section{1 研究数据}

根据中国第八次森林资源清查报告, 我国竹林 主要分布于 $40^{\circ} \mathrm{N}$ 以南地区，分布在 19 个省(自治区、 直辖市), 其中竹林面积 30 万 $\mathrm{hm}^{2}$ 以上的有福建、江 西、浙江、湖南、四川、广东、安徽、广西, 合计 占全国总面积的 $88.64 \%$, 福建、江西、浙江3省的竹 林面积占全国面积的一半(国家林业局, 2014)。以国 内“中国知网”和“维普网”数据库为基础, 以标题含 有“毛竹”且摘要含有“ $C$ 或 $N$ 或 $P$ ”为条件进行搜索, 搜集可利用文献近百篇, 共收集毛竹叶片 C、N、P 数据166个, 毛竹土壤 $\mathrm{C} 、 \mathrm{~N} 、 \mathrm{P}$ 数据 221 个, 毛竹调落 物C、N、P数据53个, 所收集文献主要分布在福建、 江西、浙江3省, 少量分布于湖南、四川、广西、安 徽、江苏、重庆等其他毛竹主产区, 研究区域覆盖 了我国毛竹绝大部分适生区 $\left(104.93^{\circ}-120.60^{\circ} \mathrm{E}\right.$, $24.93^{\circ}-32.12^{\circ} \mathrm{N}$ ), 同时记录的相关数据还包括研究 所在区域年平均气温、年降水量。文献中无法获取 到的经纬度、气温、降水量等数据, 通过其他文献 查找或者以研究区域的中心位置的气候资料作为 参考。 


\section{2 数据分析}

数据统计分析在SPSS 16.0软件下完成, 正态分 布性检验采用 K-S 检验 (one sample kolmogorovsmirnov test)方法。首先叶片、土壤以及调落物C、 $\mathrm{N} 、 \mathrm{P}$ 含量及其元素质量比数据进行以 10 为底的对数 转换, 使其符合正态分布, 再求算其算术平均值。阐 述经纬度变化模式时, 分别以经纬度为自变量, 叶 片、土壤以及调落物 $\mathrm{C} 、 \mathrm{~N} 、 \mathrm{P}$ 含量及其元素比例为 因变量做线性回归分析。分析叶片、土壤以及调落 物 $\mathrm{N} 、 \mathrm{P}$ 含量影响因素时, 分别以 $\mathrm{N} 、 \mathrm{P}$ 含量为因变量, 归一化处理后的年平均气温、年降水量为自变量做 多重线性回归分析, 利用回归斜率来判断温度、降 水对养分含量的影响。养分 $(\mathrm{N} 、 \mathrm{P})$ 再吸收率为植物 与调落物养分差值与植物养分含量的比率, 计算方 法参照王晶苑等(2011)的方法，计算公式如下：

$\mathrm{N}(\mathrm{P})$ 再吸收率 $(\%)=($ 植物 $\mathrm{N}(\mathrm{P})$ 含量-调落物 $\mathrm{N}(\mathrm{P})$ 含量 $) /$ 植物 $\mathrm{N}(\mathrm{P})$ 含量 $\times 100 \%$

\section{2 结果和分析}

\section{1 毛竹林生态化学计量特征}

\subsection{1 毛竹林叶片生态化学计量学特征}

由表1可知，毛竹林叶片 C含量为417.10-544.20 $\mathrm{mg} \cdot \mathrm{g}^{-1}$, 平均值为 $478.30 \mathrm{mg} \cdot \mathrm{g}^{-1}$; 全 $\mathrm{N}$ 含量为 6.00 $32.50 \mathrm{mg} \cdot \mathrm{g}^{-1}$, 平均值为 $22.20 \mathrm{mg} \cdot \mathrm{g}^{-1}$; $\mathrm{P}$ 含量为 0.60 $6.50 \mathrm{mg} \cdot \mathrm{g}^{-1}$, 平均值为 $1.90 \mathrm{mg} \cdot \mathrm{g}^{-1}$ 。毛竹林叶片中C、 $\mathrm{N}$ 和 $\mathrm{P}$ 变异最大的是 $\mathrm{P}$ 含量, 变异系数为 $65.19 \%$; 其 次是 $\mathrm{N}$ 含量, 变异系数为 $25.03 \%$; 最小的是 $\mathrm{C}$ 含量, 变异系数为 $7.04 \%$ 。叶片 $\mathrm{N}: \mathrm{P}$ 为 $14.40, \mathrm{C}: \mathrm{N}$ 为 26.80 , $\mathrm{C}: \mathrm{P}$ 为 299.60 , 变异系数表现为 $\mathrm{C}: \mathrm{P}>\mathrm{C}: \mathrm{N}>\mathrm{N}: \mathrm{P}$ 。

\subsection{2 毛竹林土壤生态化学计量学特征}

由表 1 可知, 毛竹林土壤 $\mathrm{C}$ 含量为 8.11-45.05 $\mathrm{mg} \cdot \mathrm{g}^{-1}$, 平均值为 $21.53 \mathrm{mg} \cdot \mathrm{g}^{-1}$; 全 $\mathrm{N}$ 含量为 0.49 $3.99 \mathrm{mg} \cdot \mathrm{g}^{-1}$, 平均值为 $1.66 \mathrm{mg} \cdot \mathrm{g}^{-1}$; 全 $\mathrm{P}$ 含量为 $0.07-$ $0.79 \mathrm{mg} \cdot \mathrm{g}^{-1}$, 平均值为 $0.41 \mathrm{mg} \cdot \mathrm{g}^{-1}$ 。毛竹林土壤中 $\mathrm{C}$ 、 $\mathrm{N}$ 和 $\mathrm{P}$ 变异最大的是 $\mathrm{N}$ 含量, 变异系数为 $43.14 \%$; 其 次是 $\mathrm{C}$ 含量, 变异系数为 $39.34 \%$; 最小的是 $\mathrm{P}$ 含量, 变异系数为 $38.04 \%$ 。土壤中 $\mathrm{N}: \mathrm{P}$ 为 $4.28, \mathrm{C}: \mathrm{N}$ 为 14.20 , $C: P$ 为 66.74, 变异系数表现为 $C: P>N: P>C: N$ 。

\subsection{3 毛竹林调落物生态化学计量学特征}

由表 1 可知, 毛竹林调落物 C 含量为 394.50$517.90 \mathrm{mg} \cdot \mathrm{g}^{-1}$, 平均值为 $438.49 \mathrm{mg} \cdot \mathrm{g}^{-1}$; 全 $\mathrm{N}$ 含量为 $5.40-30.20 \mathrm{mg} \cdot \mathrm{g}^{-1}$, 平均值为 $13.39 \mathrm{mg} \cdot \mathrm{g}^{-1}$; $\mathrm{P}$ 含量为
$0.30-2.20 \mathrm{mg} \cdot \mathrm{g}^{-1}$, 平均值为 $0.86 \mathrm{mg} \cdot \mathrm{g}^{-1}$ 。毛竹林调落 物中 $\mathrm{C} 、 \mathrm{~N}$ 和 $\mathrm{P}$ 变异最大的是 $\mathrm{P}$ 含量, 变异系数为 $67.74 \%$; 其次是 $\mathrm{N}$ 含量, 变异系数为 $50.50 \%$; 最小 的是 $\mathrm{C}$ 含量, 变异系数为 $7.22 \%$ 。调落物中 $\mathrm{N}: \mathrm{P}$ 为 $22.55, \mathrm{C}: \mathrm{N}$ 为 $25.53, \mathrm{C}: \mathrm{P}$ 为 665.67, 变异系数表现为 $\mathrm{N}: \mathrm{P}>\mathrm{C}: \mathrm{P}>\mathrm{C}: \mathrm{N}$ 。

\subsection{4 毛竹林植被-土壤-调落物系统生态化学计量} 学特征

从表1可以看出, 在毛竹林植被-土壤-调落物系 统中, 叶片和调落物中元素的变异系数均表现为: $\mathrm{P}>\mathrm{N}>\mathrm{C}$, 而土壤中元素的变异系数均表现为: $\mathrm{N}>\mathrm{C}>\mathrm{P}$; 生态化学计量特征 $\mathrm{C}: \mathrm{N}$ 表现为叶片>凋 落物 $>$ 土壤, $\mathrm{C}: \mathrm{P}$ 和 $\mathrm{N}: \mathrm{P}$ 均表现为: 调落物 $>$ 叶片 $>$ 土 壤。植物叶片 $\mathrm{N}: \mathrm{P}$ 值用来作为判断植物养分限制状 况, 本研究中我国毛竹林叶片 N:P平均值为 14.40 , 按照当 $\mathrm{N}: \mathrm{P}>16$ 表示P限制, $\mathrm{N}: \mathrm{P}<14$ 表示N限制, 14 $<\mathrm{N}: \mathrm{P}<16$ 时则同时受到 $\mathrm{N} 、 \mathrm{P}$ 限制或者不受两者限 制的理论, 我国毛竹林生长可能受到 $\mathrm{N}$ 和 $\mathrm{P}$ 元素的 双重限制。同时利用公式(1)计算可知我国毛竹 N、P 元素平均再吸收率分别为 $39.68 \%$ 和 $54.74 \%$ 。

\section{2 毛竹林系统生态化学计量特征空间变化模式 2.2.1 纬度变化模式}

从表2可以看出, 毛竹叶片的 $\mathrm{N}$ 含量、 $\mathrm{N}: \mathrm{P}$ 随着 纬度的增加而增加, $\mathrm{C}: \mathrm{N}$ 随着纬度增加而降低。而土 壤和调落物的 $\mathrm{C} 、 \mathrm{~N} 、 \mathrm{P}$ 含量及其计量比随纬度变化 未表现出明显的变化趋势。

\subsection{2 经度变化模式}

从表3中可以看出, 毛竹叶片 $\mathrm{N}: \mathrm{P}$ 随经度增加而 增加, P含量、C:N随经度增加而降低; 毛竹林土壤 $\mathrm{C}: \mathrm{N}$ 随经度增加而增加, $\mathrm{N}$ 含量随经度增加而降低； 毛竹林调落物 $\mathrm{N}$ 含量随经度增加而降低。

\subsection{3 毛竹叶片养分含量的影响因子}

以温度、降水及其组合为自变量, 毛竹叶片 $\mathrm{N}$ 和 $\mathrm{P}$ 含量为因变量做线性回归分析, 发现随着自变 量的增加，线性模型的拟合优度逐渐改善(表4)。叶 片中 $\mathrm{N}$ 含量与年平均气温和年降水量均存在明显的 线性负相关, 从回归斜率中可以看出, 叶片 $\mathrm{N}$ 含量 对温度的响应比降水更敏感。

\section{3 讨论}

\section{1 毛竹林叶片生态化学计量学特征}

我国毛竹林叶片平均 $\mathrm{C}$ 含量为 $478.30 \mathrm{mg} \cdot \mathrm{g}^{-1}$, 
表1 毛竹林植被-土壤-调落物系统生态化学计量学特征

Table 1 C, N and P stoichiometry of the forest-soil-litter system in Phyllostachys edulis forests

\begin{tabular}{|c|c|c|c|c|c|c|c|c|}
\hline & $\begin{array}{l}\text { 因变量 } \\
\text { Dependent } \\
\text { variable } \\
\end{array}$ & $n$ & $\begin{array}{l}\text { 最小值 } \\
\text { Min } \\
\left(\mathrm{mg} \cdot \mathrm{g}^{-1}\right)\end{array}$ & $\begin{array}{l}\text { 最大值 } \\
\text { Max } \\
\left(\mathrm{mg} \cdot \mathrm{g}^{-1}\right) \\
\end{array}$ & $\begin{array}{l}\text { 平均值 } \\
\text { Mean } \\
\left(\mathrm{mg} \cdot \mathrm{g}^{-1}\right)\end{array}$ & $\begin{array}{l}\text { 标准偏差 } \\
\text { Standard } \\
\text { deviation }\end{array}$ & $\begin{array}{l}\text { 变异系数 } \\
\text { Coefficient } \\
\text { of variation (\%) }\end{array}$ & $\begin{array}{l}p(\mathrm{~K}-\mathrm{S} \text { 检验) } \\
p \text { (K-S test }\end{array}$ \\
\hline \multirow[t]{6}{*}{ 叶片 Leaf } & $\mathrm{C}$ & 32 & 417.10 & 544.20 & 478.30 & 33.69 & 7.04 & 0.980 \\
\hline & $\mathrm{N}$ & 68 & 6.00 & 32.50 & 22.20 & 5.57 & 25.03 & 0.107 \\
\hline & $\mathrm{P}$ & 66 & 0.60 & 6.50 & 1.90 & 1.24 & 65.19 & 0.137 \\
\hline & $\mathrm{N}: \mathrm{P}$ & 74 & 3.22 & 32.17 & 14.40 & 6.16 & 42.66 & 0.505 \\
\hline & $\mathrm{C}: \mathrm{N}$ & 14 & 17.55 & 60.09 & 26.80 & 12.12 & 45.23 & 0.233 \\
\hline & $\mathrm{C}: \mathrm{P}$ & 12 & 192.00 & 565.94 & 299.60 & 139.77 & 46.65 & 0.080 \\
\hline \multirow[t]{6}{*}{ 土壤 Soil } & $\mathrm{C}$ & 95 & 8.11 & 45.05 & 21.53 & 8.47 & 39.34 & 0.832 \\
\hline & $\mathrm{N}$ & 85 & 0.49 & 3.99 & 1.66 & 0.72 & 43.14 & 0.953 \\
\hline & $\mathrm{P}$ & 41 & 0.07 & 0.79 & 0.41 & 0.16 & 38.04 & 0.087 \\
\hline & $\mathrm{N}: \mathrm{P}$ & 41 & 1.29 & 7.83 & 4.28 & 1.78 & 41.44 & 0.670 \\
\hline & C:N & 81 & 5.35 & 32.12 & 14.20 & 4.51 & 31.80 & 0.784 \\
\hline & C:P & 41 & 23.61 & 224.86 & 66.74 & 39.32 & 58.92 & 0.600 \\
\hline \multirow[t]{6}{*}{ 调落物 Litter } & $\mathrm{C}$ & 12 & 394.50 & 517.90 & 438.49 & 31.67 & 7.22 & 0.511 \\
\hline & $\mathrm{N}$ & 21 & 5.40 & 30.20 & 13.39 & 6.76 & 50.50 & 0.892 \\
\hline & $\mathrm{P}$ & 20 & 0.30 & 2.20 & 0.86 & 0.58 & 67.74 & 0.742 \\
\hline & $\mathrm{N}: \mathrm{P}$ & 20 & 3.00 & 54.25 & 22.55 & 15.18 & 67.32 & 0.989 \\
\hline & C:N & 9 & 14.52 & 44.74 & 25.53 & 9.63 & 37.72 & 0.923 \\
\hline & $\mathrm{C}: \mathrm{P}$ & 8 & 219.25 & 1096.25 & 665.67 & 324.97 & 48.82 & 0.639 \\
\hline
\end{tabular}

表2 毛竹林植被-土壤-调落物碳 $(\mathrm{C})$ 、氮 $(\mathrm{N})$ 、磷 $(\mathrm{P})$ 含量及其计量比的纬 度变化模式

Table 2 Latitudinal patterns of carbon (C), nitrogen (N) and phosphorus (P) contents and their ratios in plant-soil-litter

\begin{tabular}{|c|c|c|c|c|c|c|}
\hline & $\begin{array}{l}\text { 因变量 } \\
\text { Dependent } \\
\text { variable }\end{array}$ & $\begin{array}{l}\text { 截距 } \\
\text { Intercept }\end{array}$ & $\begin{array}{l}\text { 斜率 } \\
\text { Slope }\end{array}$ & $R^{2}$ & $p$ & $n$ \\
\hline$\overline{\text { 叶片 }}$ & $\mathrm{C}$ & 2.619 & 0.002 & 0.019 & 0.449 & 32 \\
\hline \multirow[t]{5}{*}{ Leaf } & $\mathrm{N}$ & -0.037 & 0.047 & 0.368 & $<0.001$ & 68 \\
\hline & $P$ & 0.657 & -0.015 & 0.012 & 0.390 & 66 \\
\hline & $\mathrm{N}: \mathrm{P}$ & -0.313 & 0.048 & 0.120 & 0.002 & 74 \\
\hline & $\mathrm{C}: \mathrm{N}$ & 3.069 & -0.057 & 0.602 & $<0.001$ & 14 \\
\hline & $\mathrm{C}: \mathrm{P}$ & -5806.047 & 201.231 & 0.204 & 0.141 & 12 \\
\hline 土壤 & $\mathrm{C}$ & 1.252 & 0.002 & 0.000 & 0.835 & 95 \\
\hline \multirow[t]{5}{*}{ Soil } & $\mathrm{N}$ & -0.131 & 0.011 & 0.015 & 0.270 & 85 \\
\hline & $\mathrm{P}$ & -0.456 & 0.001 & 0.000 & 0.937 & 41 \\
\hline & $\mathrm{N}: \mathrm{P}$ & 0.005 & 0.021 & 0.070 & 0.098 & 41 \\
\hline & $\mathrm{C}: \mathrm{N}$ & 1.239 & -0.004 & 0.003 & 0.621 & 81 \\
\hline & $\mathrm{C}: \mathrm{P}$ & 1.385 & 0.014 & 0.026 & 0.316 & 41 \\
\hline 调落物 & $\mathrm{C}$ & 2.697 & -0.002 & 0.007 & 0.798 & 12 \\
\hline \multirow[t]{5}{*}{ Litter } & $\mathrm{N}$ & 63.793 & -1.668 & 0.178 & 0.057 & 21 \\
\hline & $\mathrm{P}$ & -0.084 & -0.002 & 0.000 & 0.955 & 20 \\
\hline & $\mathrm{N}: \mathrm{P}$ & 3.152 & -0.064 & 0.074 & 0.247 & 20 \\
\hline & $\mathrm{C}: \mathrm{N}$ & 2.304 & -0.032 & 0.074 & 0.479 & 9 \\
\hline & $\mathrm{C}: \mathrm{P}$ & 4613.437 & -135.896 & 0.299 & 0.161 & 8 \\
\hline
\end{tabular}

表3 毛竹林植被-土壤-调落物碳 $(\mathrm{C})$ 、氮 $(\mathrm{N})$ 、磷 $(\mathrm{P})$ 含量及其计量比的经 度变化模式

Table 3 Longitudinal patterns of carbon (C), nitrogen (N) and phosphorus (P) contents and their ratios in plant-soil-litter

\begin{tabular}{|c|c|c|c|c|c|c|}
\hline & $\begin{array}{l}\text { 因变量 } \\
\text { Dependent } \\
\text { variable }\end{array}$ & $\begin{array}{l}\text { 截距 } \\
\text { Intercept }\end{array}$ & $\begin{array}{l}\text { 斜率 } \\
\text { Slope }\end{array}$ & $R^{2}$ & $p$ & $n$ \\
\hline 叶片 & $\mathrm{C}$ & 2.842 & -0.001 & 0.047 & 0.232 & 32 \\
\hline \multirow{5}{*}{ Leaf } & $\mathrm{N}$ & 1.171 & 0.001 & 0.001 & 0.790 & 68 \\
\hline & $\mathrm{P}$ & 4.070 & -0.033 & 0.253 & $<0.001$ & 66 \\
\hline & $\mathrm{N}: \mathrm{P}$ & -2.650 & 0.032 & 0.246 & $<0.001$ & 74 \\
\hline & $\mathrm{C}: \mathrm{N}$ & 14.897 & -0.113 & 0.513 & 0.004 & 14 \\
\hline & $\mathrm{C}: \mathrm{P}$ & 11.947 & -0.080 & 0.184 & 0.164 & 12 \\
\hline 土壤 & $\mathrm{C}$ & 2.669 & -0.012 & 0.032 & 0.084 & 95 \\
\hline \multirow[t]{5}{*}{ Soil } & $\mathrm{N}$ & 2.115 & -0.016 & 0.053 & 0.035 & 85 \\
\hline & $\mathrm{P}$ & 1.025 & -0.012 & 0.029 & 0.290 & 41 \\
\hline & $\mathrm{N}: \mathrm{P}$ & 2.131 & -0.013 & 0.036 & 0.235 & 41 \\
\hline & C:N & -0.275 & 0.012 & 0.051 & 0.044 & 81 \\
\hline & $\mathrm{C}: \mathrm{P}$ & 0.469 & 0.011 & 0.022 & 0.353 & 41 \\
\hline 调落物 & $\mathrm{C}$ & 2.563 & 0.001 & 0.016 & 0.698 & 12 \\
\hline \multirow[t]{5}{*}{ Litter } & $\mathrm{N}$ & 2.883 & -0.060 & 0.209 & 0.037 & 21 \\
\hline & $\mathrm{P}$ & -0.561 & 0.003 & 0.002 & 0.858 & 20 \\
\hline & $\mathrm{N}: \mathrm{P}$ & -0.124 & 0.011 & 0.010 & 0.669 & 20 \\
\hline & $\mathrm{C}: \mathrm{N}$ & 3.037 & -0.014 & 0.196 & 0.232 & 9 \\
\hline & C:P & 6.433 & -0.031 & 0.415 & 0.085 & 8 \\
\hline
\end{tabular}


表4 叶片氮 $(\mathrm{N})$ 、磷 $(\mathrm{P})$ 含量及其影响因子的线性回归关系

Table 4 Linear regression relationship between leaf nitrogen $(\mathrm{N})$ and phosphorus $(\mathrm{P})$ contents and the environmental factors

\begin{tabular}{|c|c|c|c|c|c|c|}
\hline & \multicolumn{3}{|c|}{$\mathrm{N}$} & \multicolumn{3}{|c|}{$\mathrm{P}$} \\
\hline & $\begin{array}{l}\text { 斜率 } \\
\text { Slope }\end{array}$ & $R^{2}$ & $n$ & $\begin{array}{l}\text { 斜率 } \\
\text { Slope }\end{array}$ & $R^{2}$ & $n$ \\
\hline 年平均气温 $\mathrm{MAT}$ & -0.324 & $0.205^{* * *}$ & 68 & -0.144 & 0.015 & 66 \\
\hline 年降水量 MAP & -0.308 & $0.191^{* * *}$ & 68 & -0.281 & 0.057 & 66 \\
\hline $\begin{array}{l}\text { 年平均气温+年降水量 } \\
\text { MAT + MAP }\end{array}$ & & $0.226^{* * *}$ & 68 & & 0.065 & 66 \\
\hline
\end{tabular}

MAP, mean annual precipitation; MAT, mean annual temperature. ${ }^{* *}, p<$ $0.01 ; * * *, p<0.001$.

落在国际上公认的植物平均 C含量 $45 \%-50 \%$ 区间内 (刘国华等, 2000; 方精云等, 2001; 曹军等, 2002), 同时, 采用 $47.8 \%$ 作为毛竹叶片 $\mathrm{C}$ 含量来估算森林生 态系统乔木层 $\mathrm{C}$ 储量和 $\mathrm{C}$ 计量参数, 估计结果更为 准确。毛竹林叶片 $\mathrm{C}$ 含量与我国东部南北样带森林 102 种优势种叶片 (480.1 mg.g ${ }^{-1}$ ) 相似(任书杰等, 2012), 略高于全球492种陆地植物叶片 $\mathrm{C}$ 含量的几 何平均数 $\left((464 \pm 32.1) \mathrm{mg} \cdot \mathrm{g}^{-1}\right)$ (Elser et al., 2000a)、 北京周边 358 个物种叶片 $\mathrm{C}$ 含量 $\left(451.0 \mathrm{mg} \cdot \mathrm{g}^{-1}\right)$ (韩文 轩等, 2009), 说明毛竹叶片有机化合物含量较高, 叶片具有更强的 $C$ 存储能力, 这一方面缘于毛竹的 适生区域光照充足、雨水充沛，提供了更好的水热 条件; 另一方面可能与毛竹特有的生物学特性有 关，毛竹既不同于阔叶树也不同于针叶树，其茎秆 内存在类似 $\mathrm{C}_{4}$ 植物的花环结构, 可能存在 $\mathrm{C}_{4}$ 光合途 径, 有利于毛竹提高光合效率, 这可能造成叶片 $\mathrm{C}$ 含量高于其他树种(王星星等, 2012)。

我国毛竹林叶片平均 $\mathrm{N}$ 含量为 $22.20 \mathrm{mg} \cdot \mathrm{g}^{-1}$, 高 于我国 753 种陆生植物叶片 $\mathrm{N}$ 含量的几何平均数 (18.6 mg.g $\left.{ }^{-1}\right)($ Han et al., 2005), 我国东部南北样带 102 个优势种叶片的 $\mathrm{N}$ 含量 $\left(18.6 \mathrm{mg} \cdot \mathrm{g}^{-1}\right)$ (任书杰等, 2012), 我国东部南北样带654种植物叶片 $\mathrm{N}$ 含量的 几何平均数 (17.55 mg.g ${ }^{-1}$ )(任书杰等, 2007), 浙江天 童山 32 种常绿阔叶树 $\mathrm{N}$ 含量 $\left(16.06 \mathrm{mg} \cdot \mathrm{g}^{-1}\right.$ ) (阎恩荣 等, 2010); 低于北京周边 358 个物种叶片 $\mathrm{N}$ 含量(26.1 $\mathrm{mg} \cdot \mathrm{g}^{-1}$ )(韩文轩等, 2009), 科尔沉沙地52种植物叶片 $\mathrm{N}$ 含量(24.7 mg.g ${ }^{-1}$ )(赵红洋等, 2010), 黄土高原区 126 种植物叶片 $\mathrm{N}$ 含量 $\left(24.1 \mathrm{mg} \cdot \mathrm{g}^{-1}\right)$ (郑淑霞和上官周 平, 2006)。有研究表明不同生活型叶片养分含量具 有明显差异, 与落叶树种相比, 常绿树种有较低的 $\mathrm{N} 、 \mathrm{P}$ 含量, 通常被认为是寡养生境的一种适应, 常 绿树能通过较长的叶寿命减少养分损失, 以提高自
身养分胁迫环境下的竞争力(阎恩荣等, 2010); 另一 方面, $\mathrm{N}$ 素与植物生长区域降水有关, 大部分毛竹的 适生区域水量充沛，而植物吸收利用的 $\mathrm{N}$ 素大多以 可溶性的硝态氮和铵态氮为主, 而较大的降水量能 够导致 $\mathrm{N}$ 淋溶, 使植物可以吸收利用的有效氮减少 (马玉珠等, 2015), 因此毛竹叶片 $\mathrm{N}$ 素含量高于生长 在降水量更多的中国东部地区的常绿树种, 而低于 生长在降水量较少的西北干旱地区的落叶树种。

我国毛竹林叶片平均 $\mathrm{P}$ 含量为 $1.90 \mathrm{mg} \cdot \mathrm{g}^{-1}$ ，与北 京周边 358 个物种叶片 $\mathrm{P}$ 含量 $\left(2.0 \mathrm{mg} \cdot \mathrm{g}^{-1}\right)$ (韩文轩等, 2009), 我国东部南北样带 102 个优势种的 $\mathrm{P}$ 含量(2.0 $\left.\mathrm{mg} \cdot \mathrm{g}^{-1}\right)$ (任书杰等, 2012)相似; 高于杭州湿地3种草 本植物 $\mathrm{P}$ 含量 $\left(0.74-0.93 \mathrm{mg} \cdot \mathrm{g}^{-1}\right)$ (吴统贵等, 2010$)$, 浙江天童山 32 种常绿阔叶树 $\mathrm{P}$ 含量 $\left(0.86 \mathrm{mg} \cdot \mathrm{g}^{-1}\right)$ (阎 恩荣等, 2010), 福建 101 种木本植物叶片 $\mathrm{P}$ 含量的几 何平均数 $\left(0.94 \mathrm{mg} \cdot \mathrm{g}^{-1}\right.$ ) (林志斌等, 2011), 我国 753种 陆生植物叶片 $\mathrm{P}$ 含量的几何平均数 $\left(1.21 \mathrm{mg} \cdot \mathrm{g}^{-1}\right)(\mathrm{Han}$ et al., 2005), 我国东部南北样带654中植物叶片 $\mathrm{P}$ 含 量的几何平均数 (1.28 $\left.\mathrm{mg} \cdot \mathrm{g}^{-1}\right)$ (任书杰等, 2007), 黄 土高原区126种植物叶片 $\mathrm{P}$ 含量 $\left(1.6 \mathrm{mg} \cdot \mathrm{g}^{-1}\right)$ (郑淑霞 和上官周平, 2006); 低于科尔沁沙地 52 种植物叶片 P含量 $\left(2.60 \mathrm{mg} \cdot \mathrm{g}^{-1}\right)$ (赵红洋等, 2010)。这可能缘于毛 竹相比其他树种具有更快的生长速度和更高的生产 力, 而叶片作为主要的光合器官需要合成大量的蛋 白质和核苷酸, 尤其是在装配酶的过程中需要大量 核酸的复制(Michaels, 2003), rRNA含量增加导致植 物体细胞中 $\mathrm{P}$ 浓度上升, 从而毛竹林叶片 $\mathrm{P}$ 含量一般 高于其他树种。

从我国毛竹林叶片 $\mathrm{C}: \mathrm{N} 、 \mathrm{C}: \mathrm{P}$ 和 $\mathrm{N}: \mathrm{P}$ 与其他已有 研究结果的对比中可以看出(表5), 我国毛竹林叶片 C:N (26.80)值小于我国东部南北样地NSTEC、浙江、 滇池等地区，而明显大于黄土高原、北京、塔克拉 玛干沙漠等降水较少的地区，这与毛竹叶片中N元 素含量有关。有研究表明适度干旱能够提高植物对 $\mathrm{N}$ 的吸收效率和降低植物生长速率, 最终导致植物 的C:N降低(Lu et al., 2009)。毛竹林叶片C:P值与全 球区域下植被C:P相似，明显低于NSTEC、浙江等, 略高于北京和塔克拉玛干沙漠等, 与叶片 $\mathrm{P}$ 含量变 化趋势相反。毛竹林叶片拥有较低的 N:P值(14.40), 这主要是因为毛竹具有较快的生长速度, 而植物体 的生长速度决定于蛋白质的合成速度, 在细胞中 $\mathrm{P}$ 的存在形式多以核酸磷存在, 所以高速生长的植物 
表5 我国毛竹林叶片C:N、C:P和N:P与其他已有研究结果的对比

Table 5 Comparisons of C:N, C:P and N:P of Phyllostachys edulis leaf in China to previous studies

\begin{tabular}{lllll}
\hline 研究区域 Study area & C:N & C:P & N:P & 数据来源 Reference \\
\hline 全国毛竹林 National bamboo forest & 26.80 & 299.60 & 14.40 & This study \\
全球 Global & $23.80^{*}$ & $300.90^{*}$ & 13.80 & Elser et al., 2000a, 2000b; Reich \& Oleksyn, 2004 \\
NSTEC & & & $13.50^{*}$ & Ren et al., 2007 \\
& 29.10 & 313.9 & 11.50 & Ren et al., 2012 \\
浙江天童山 Tiantongshan, Zhejiang & 42.10 & 758.00 & 18.00 & Yan et al., 2010 \\
& 48.40 & 678.00 & 14.00 & Yan et al., 2010 \\
& 30.70 & 338.00 & 11.00 & Yan et al., 2010 \\
滇池流域 Dianchi area & 37.71 & 267.50 & 8.60 & Yan et al., 2011 \\
黄土高原 Losses Plateau & 21.20 & 312.00 & 15.40 & Zheng \& Shangguan, 2006 \\
塔克拉玛干沙漠 Taklimakan Desert & 17.50 & 249.00 & 15.00 & Li et al., 2013 \\
北京及周边 Beijing and surrounding area & 17.30 & 242.00 & 13.90 & Han et al., 2009 \\
福建万木林 Wanmulin, Fujian & & & $18.49^{*}$ & Lin et al., 2011 \\
杭州湾滨海湿地 Hangzhou Bay Coastal Wetlands & & & 16.49 & Wu et al., 2010 \\
松嫩平原 Songnen Plain & & & 13.00 & Song et al., 2012 \\
\hline
\end{tabular}

*, 几何平均值。

*, geometric average.

表6 我国毛竹林 $0-20 \mathrm{~cm}$ 土壤层 $\mathrm{C}: \mathrm{N} 、 \mathrm{C}: \mathrm{P}$ 和 $\mathrm{N}: \mathrm{P}$ 与其他已有研究结果的对比

Table 6 Comparisons of soil C:N, C:P and N:P in Phyllostachys edulis forest in China to previous studies

\begin{tabular}{lllll}
\hline 研究区域 Study area & C:N & C:P & N:P & 数据来源 Reference \\
\hline 全国毛竹林 National bamboo forest & 14.20 & 66.74 & 4.28 & This study \\
全球森林0-10 cm Global forest 0-10 cm & 12.40 & 81.90 & 6.60 & Cleveland \& Liptzin, 2007 \\
全球草地 $0-10 \mathrm{~cm}$ Global grassland 0-10 cm & 11.80 & 64.30 & 5.60 & Cleveland \& Liptzin, 2007 \\
中国极寒高原 Cold plateau of China & 11.70 & 24.00 & 2.70 & Tian et al., 2010 \\
中国有机土 Organic soil in China & 14.90 & 131.60 & 8.00 & Tian et al., 2010 \\
黄土高原0-10 cm Loess Plateau 0-10 cm & 12.92 & 22.85 & 1.88 & Zhang et al., 2013 \\
塔克拉玛干沙漠 Taklimakan Desert & 14.80 & 2.69 & 0.18 & Li et al., 2013 \\
南亚热带森林0-10 cm Sub-tropical forest in South China 0-10 cm & & & 2.30 & Liu et al., 2010 \\
& & & 2.50 & Liu et al., 2010 \\
& & & 3.60 & Liu et al., 2010 \\
\hline
\end{tabular}

体中P的浓度都较高(Ågren, 2004), 进而导致生物体 氮、磷元素总量发生不同速率变化, 从而改变生物 体内C:P和N:P (Elser et al., 2003), 这与生长速率假 说/理论相符。但也有研究表明高 $\mathrm{C}$ 含量叶植物一般 具有较低的 $N$ 和P, 叶片 C和N、P的显著负相关是高 等植物元素计量的普遍规律, 体现了植物在固 $\mathrm{C}$ 过 程中利用效率的权衡策略(Aerts \& Chapin III, 2000; Wright et al., 2004)。

\section{2 毛竹林土壤生态化学计量学特征}

我国毛竹林 0-20 $\mathrm{cm}$ 土壤层土壤有机碳(SOC) 含量为 $8.11-45.05 \mathrm{mg} \cdot \mathrm{g}^{-1}$, 平均值为 $21.53 \mathrm{mg} \cdot \mathrm{g}^{-1}$, 高于我国黄土高原区0-10 cm刺槐(Robinia pseudo- acacia $)$ 林的 SOC 含量 $\left(10.20 \mathrm{mg} \cdot \mathrm{g}^{-1}\right)$ (张向茹等, 2013)，江苏全省 0-20 $\mathrm{cm}$ 土壤 SOC 含量 (16.55 $\mathrm{mg} \cdot \mathrm{g}^{-1}$ ) (赵明松等, 2013), 贑中地区 4 种林分 0-10 $\mathrm{cm}$ 土壤层SOC含量 $\left(16.27 \mathrm{mg} \cdot \mathrm{g}^{-1}\right)$ (杜满义等, 2013), 干热河谷不同土地利用类型下 $0-20 \mathrm{~cm}$ 土壤层 $\mathrm{SOC}$ 含量(4.22-5.19 mg. $\mathrm{g}^{-1}$ )(唐国勇等, 2010); 低于我国 云南普洱季风常绿阔叶林不同演替阶段森林 $0-20$ $\mathrm{cm}$ 土壤层SOC含量(31.2、45.8、56.9 $\mathrm{mg} \cdot \mathrm{g}^{-1}$ )(刘万德 等, 2010), 三工河流域 0-20 cm 土壤层SOC含量 $\left(34.26 \mathrm{mg} \cdot \mathrm{g}^{-1}\right)$ (许文强等, 2009)。植被类型对土壤有 机碳的影响具有显著作用, 分析表明毛竹林土壤层 碳含量处于较高水平, 土壤层碳含量主要取决于土 
壤中有机质的输入与输出的平衡, 这可能缘于毛竹 林特有的鞭根系统，具有分布浅，生物量大，细根 周转速度快(范少辉等, 2009), 以及毛竹林地上调落 物分解对林地碳源进行了必要的补充和供给, 同时 气候因素对生物量对碳积累的影响显著,一般认为, 湿润条件下更有利于碳的积累(白军红等, 2003)。

我国毛竹林 $0-20 \mathrm{~cm}$ 土壤层全 $\mathrm{N}$ 含量为 0.49 $3.99 \mathrm{mg} \cdot \mathrm{g}^{-1}$, 平均值为 $1.66 \mathrm{mg} \cdot \mathrm{g}^{-1}$, 高于我国黄土高 原区 $0-10 \mathrm{~cm}$ 刺槐林的全氮含量 $\left(0.92 \mathrm{mg} \cdot \mathrm{g}^{-1}\right)($ 张向 茹等, 2013), 赣中地区 4 种林分 $0-10 \mathrm{~cm}$ 土壤层全 $\mathrm{N}$ 含量 $\left(0.63-0.94 \mathrm{mg} \cdot \mathrm{g}^{-1}\right)$ (杜满义等, 2013), 低于四川 西北部亚高山典型森林植被类型土壤层 $\mathrm{N}$ 含量 (2.74-6.51 mg $\left.\cdot \mathrm{g}^{-1}\right)$ (刘跃建等, 2010), 西双版纳季风 常绿阔叶林0-20 cm 土层全 $\mathrm{N}$ 含量 $\left(1.94 \mathrm{mg} \cdot \mathrm{g}^{-1}\right.$ )(李明 锐和沙丽清, 2005)。土壤中C、N元素具有耦合作用, 且土壤碳库与氮库存在正相关性, 这是因为当土壤 中 $\mathrm{C}$ 含量增加时, 土壤微生物更多进行 $\mathrm{N}$ 累积过程 而非 $\mathrm{N}$ 矿化过程, 大部分的 $\mathrm{N}$ 元素参与到有机质的 合成过程, 最终降低N矿化速率(Mclauchlan et al., 2006)。土壤C、N均受到调落物归还量的影响, 在降 水量较少和温度较低的区域, 植被茂盛程度较低, 调落物量小的区域 $\mathrm{N}$ 含量较低, 相反, 在雨量充沛 和光照充足的区域, 植被种类丰富、调落物归还量 大, 有利于土壤中 $\mathrm{N}$ 素的积累, 但雨量增大的同时 会加剧土壤中有效氮的淋溶作用。

我国毛竹林 $0-20 \mathrm{~cm}$ 土壤层全 $\mathrm{P}$ 含量为 $0.07-$ $0.79 \mathrm{mg} \cdot \mathrm{g}^{-1}$, 平均值为 $0.41 \mathrm{mg} \cdot \mathrm{g}^{-1}$, 高于赣中地区 4 种林分 $0-10 \mathrm{~cm}$ 土壤层全 $\mathrm{P}$ 含量 $\left(0.10-0.12 \mathrm{mg} \cdot \mathrm{g}^{-1}\right)$ (杜满义等, 2013); 与天目山国家自然保护区针阔混 交林 $0-20 \mathrm{~cm}$ 土壤层全P含量 $\left(0.45 \mathrm{mg} \cdot \mathrm{g}^{-1}\right.$ ) 相当(吴家
森等, 2008), 小于疏勒河上游7种土地类型0-20 cm 土壤层全 $\mathrm{P}$ 含量 $\left(0.50 \mathrm{mg} \cdot \mathrm{g}^{-1}\right)$, 研究表明土壤全磷含 量与年平均气温和土壤粉粒含量正相关, 而与年降 雨量显著负相关(刘文杰等, 2012), 在高温和雨量充 沛的地区土壤的风化速率快, 加剧 $\mathrm{P}$ 元素的淋溶, 从而导致土壤 $\mathrm{P}$ 含量降低。同时, 土壤环境条件也是 影响土壤P含量的重要因素, 毛竹的适生区域土壤 多为偏酸性，而酸性土壤中，磷酸盐容易被 $\mathrm{Fe} 、 \mathrm{Al}$ 、 $\mathrm{Mn}$ 等氧化物表面吸附或者被 $\mathrm{Al}$ 离子吸附, 能够有 效降低雨水的淋溶作用(赵琼和曾德慧, 2005), 所 以在毛竹林适生区域土壤中 $\mathrm{P}$ 元素处于中等水平。

从表6中可以看出, 我国毛竹林0-20 cm工壤层 $\mathrm{C}: \mathrm{N}$ 值与中国有机土的比值接近, 而高于全球 $0-10$ $\mathrm{cm}$ 森林土壤层的比值。土壤 $\mathrm{C}: \mathrm{N}$ 较高表示有机质具 有较慢的矿化作用, 土壤的有效氮含量也较低。在 内蒙古草原的实验表明, 额外増水可以增加土壤 $\mathrm{N}$ 的矿化速率(Lü et al., 2012), 但雨量充沛的区域容 易发生 $\mathrm{N}$ 淋溶, 所以很有可能出现 $\mathrm{N}$ 元素的限制。我 国毛竹林 $0-20 \mathrm{~cm}$ 土壤层 $\mathrm{C}: \mathrm{P}$ 值与全球草地 $0-10 \mathrm{~cm}$ 土壤层的 $\mathrm{C}: \mathrm{P}$ 值接近, 低于全国 $0-10 \mathrm{~cm}$ 森林土壤层 的 C:P值, 高于黄土高原区和沙漠区等地区 $\mathrm{C}: \mathrm{P}$ 值, 这是由于 $\mathrm{P}$ 含量从干旱半干旱地区到湿润地区有不 断降低的趋势, C含量有增加趋势(丁小慧等, 2012)。

\section{3 毛竹林调落物生态化学计量学特征}

毛竹林调落物 $\mathrm{C}$ 含量为 $394.50-517.90 \mathrm{mg} \cdot \mathrm{g}^{-1}$, 平均值为 $438.49 \mathrm{mg} \cdot \mathrm{g}^{-1}$ 。毛竹调落物 $\mathrm{C}$ 含量一方面与 新鲜叶片中C含量密切相关, 另一方面也与调落物 分解程度有关, 调落物在分解过程中会以 $\mathrm{CO}_{2}$ 的形 式释放出化合物中的 $\mathrm{C}$, 所以调落物 C含量(438.49 $\mathrm{mg} \cdot \mathrm{g}^{-1}$ )略低于叶片中C含量 $\left(478.30 \mathrm{mg} \cdot \mathrm{g}^{-1}\right)$ 。对于参

表7 我国毛竹林调落物 $\mathrm{C}: \mathrm{N} 、 \mathrm{C}: \mathrm{P}$ 和 $\mathrm{N}: \mathrm{P}$ 与其他已有研究结果的对比

Table 7 Comparisons of C: N, C: P and N: P of Phyllostachys edulis litter in China to previous studies

\begin{tabular}{lllll}
\hline 研究区域 Study area & C:N & C:P & N:P & 数据来源 Reference \\
\hline 全国毛竹林 National bamboo forest & 25.53 & 665.67 & 22.55 & This study \\
全球森林 Global forest & 57.3 & 1175.60 & 20.30 & McGroddy et al, 2004 \\
吉林长白山 Changbai Mountain, Jilin & 39.43 & 552.00 & 14.00 & Wang et al., 2011 \\
广东鼎湖山 Dinghu Mountain, Guangdong & 29.57 & 1035.00 & 35.00 & Wang et al., 2011 \\
云南西双版纳 Xishuangbanna, Yunnan & 30.12 & 723.00 & 24.00 & Wang et al., 2011 \\
江西千烟洲 Qianyanzhou, Jiangxi & 72.22 & 1950.00 & 27.00 & Wang et al., 2011 \\
浙江天童山 Tiantongshan, Zhejiang & 59.77 & 777.00 & 13.00 & Yan et al., 2010 \\
& 49.36 & 691.00 & 14.00 & Yan et al., 2010 \\
& 40.50 & 567.00 & 14.00 & Yan et al., 2010 \\
\hline
\end{tabular}


与循环的元素 $\mathrm{N}$ 和 $\mathrm{P}$ 来说, 它在植物体内能够转移 和多次利用, 大多数分布在生长点和嫩叶等代谢比 较旺盛的部分, 其元素缺失大多发生在老叶和落叶 中, 即当植物落叶时, 这些可移动元素 $(\mathrm{N} 、 \mathrm{P})$ 由叶片 运往茎干或者根部, 进行重新分配和利用, 因此调 落物中的 $\mathrm{N} 、 \mathrm{P}$ 含量 $\left(13.39 \mathrm{mg} \cdot \mathrm{g}^{-1} 、 0.86 \mathrm{mg} \cdot \mathrm{g}^{-1}\right)$ 均小 于叶片中 $\mathrm{N} 、 \mathrm{P}$ 含量 $\left(22.20 \mathrm{mg} \cdot \mathrm{g}^{-1} 、 1.90 \mathrm{mg} \cdot \mathrm{g}^{-1}\right)$ 。

表7显示我国毛竹林调落物 $\mathrm{C}: \mathrm{N} 、 \mathrm{C}: \mathrm{P}$ 和 $\mathrm{N}: \mathrm{P}$ 与其 他已有研究结果的对比结果, 从表中可以发现我国 毛竹林 $\mathrm{C}: \mathrm{N}$ 和 $\mathrm{C}: \mathrm{P}$ 值小于已有大部分研究, 这可能与 毛竹叶片调落物中 $\mathrm{N} 、 \mathrm{P}$ 含量较高有关, 因此也有研 究表明毛竹叶调落物的归还有利于生产力的长期维 持(刘广路, 2009)。N:P值低于广东鼎湖山和江西千 烟洲, 而高于全球森林。有研究表明: 不同生活型 植物 $\mathrm{N} 、 \mathrm{P}$ 养分元素重吸收机制具有很大差异, 例如: 常绿植物在叶片调落之前与落叶植物相比, 能够转 移更多的养分, 这造成调落物生态化学计量指标的 差异(Aerts \& Chapin III, 2000)。也有研究表明枯落 物 $\mathrm{C}: \mathrm{N} 、 \mathrm{C}: \mathrm{P}$ 和 $\mathrm{N}: \mathrm{P}$ 的变化与植物活体表现出一致的 规律, 与枯落物秉承植物活体的特性密切相关(王 维奇等, 2011), 在本研究中这一点也有所体现。

\section{4 毛竹林植物-土壤-调落物系统生态化学计量学 特征}

生态系统组分间生态化学计量的关联具体到植 物生态学, 主要表现为 $\mathrm{C}: \mathrm{N}: \mathrm{P}$ 如何从高 $\mathrm{C}: \mathrm{N}$ 和 $\mathrm{C}: \mathrm{P}$ 通 过代谢过程传递到低C:N和C:P (植物组织: 叶片和 根系)的过程和机理(贺金生和韩兴国, 2010)。植物活 体-枯落物-土壤系统是一个紧密联系的复杂统一的 有机整体, 土壤是植物生长的载体和主要养分来源, 植物光合作用固定 $\mathrm{C}$ 并产生有机物, 同时转移或以 调落物形式补偿到土壤中, 枯落物分解后养分返还 土壤, 植物体可进行重吸收, 因此整个系统的 $\mathrm{C} 、 \mathrm{~N}$ 、 $\mathrm{P}$ 含量及其比率为主的生态化学计量特征具有明显 的关联性和差异性(Ladanai et al., 2010)。Jackson等 (1997)的研究发现全球植被细根的 C:N:P与叶片的 比值相近, 但均小于调落物的 $\mathrm{C}$ 与养分元素的比值, 这可能与植物的重吸收作用有关; 王晶苑等(2011) 研究中国4种森林类型的生态化学计量特征, 发现 不同类型森林的叶片与调落物的化学计量特征具有 一致性; 曾冬萍等(2013)发现植物凋落物在不同功 能群尺度上表现出不同的生态化学计量特征, 且与 植物活体具有相似的变化规律。本研究中得出相似
结果, 毛竹调落物 $\mathrm{C}: \mathrm{P} 、 \mathrm{~N}: \mathrm{P}$ (665.67、22.55)值大于 叶片(299.60、14.40), 而两者 $\mathrm{C}: \mathrm{N}$ 值相近; 但Vitousek (2003)的研究发现桃金娘 (Rhodomyrtus tomentosa) 花、叶片、调落物、根和木质部的 C:N值在不同生 态系统中差异很大, 但是 N:P值基本接近。植物体土壤方面, 刘万德等(2010)研究云南普洱地区常绿 阔叶林生态系统中植物与土壤 $\mathrm{C} 、 \mathrm{~N} 、 \mathrm{P}$ 生态化学计 量, 研究结果认为植物与土壤中的 $\mathrm{N} 、 \mathrm{P}$ 具有显著的 线性正相关, 说明土壤中 $\mathrm{N} 、 \mathrm{P}$ 的供应量影响着植物 体中的N、P含量。阎凯等(2011)研究认为滇池流域 富磷区植被叶片的 $\mathrm{P}$ 含量及 $\mathrm{N}: \mathrm{P}$ 与土壤磷水平呈显 著相关。在桂西北喀斯特地区(曾昭霞等, 2015)和降 雨量较少的黄土高原区(杨佳佳等, 2014), 森林土壤 的C:N、C:P、N:P值均低于叶片和枯落物, 与本文所 得出结论一致。植物-土壤-调落物表现出不同的化 学计量比特征, 这与植物的选择性吸收有一定关系, 植物根据自身所需的营养元素来选择性地吸收土壤 中的 $\mathrm{C} 、 \mathrm{~N}$ 和P元素, 而这种计量关系特征还需要进 行深入地研究和探讨(杨佳佳等, 2014)。

\section{5 毛竹林养分限制元素}

Koerselman和Meuleman (1996)根据在不同植 物体上进行的施肥实验得出, 当 $\mathrm{N}: \mathrm{P}>16$ 表示 $\mathrm{P}$ 限 制, $\mathrm{N}: \mathrm{P}<14$ 表示N限制, $14<\mathrm{N}: \mathrm{P}<16$ 时则同时受到 $\mathrm{N} 、 \mathrm{P}$ 限制或者不受两者限制(Tessier \& Raynal, 2003)。根据此判断标准, 我国毛竹叶片 N:P值为 14.40 , 说明 $\mathrm{N}$ 和 $\mathrm{P}$ 两种元素可能均为我国毛竹林限 制性元素。根据相对重吸收假说(Han et al., 2013)以 及本文中得到的结果 $(\mathrm{N} 、 \mathrm{P}$ 再吸收率分别为 $39.68 \%$ 和 54.74\%; C:N表现为: 叶片>凋落物, $\mathrm{C}: \mathrm{P}$ 和 $\mathrm{N}: \mathrm{P}$ 表 现为: 调落物 $>$ 叶片), 初步判断我国毛竹的生长很 可能更多地受到P元素的限制。也有不同的研究结 果认为这种限制在不同地域不同物种上表现不一 致, Zhang等(2004)对我国内蒙古地区草原的施肥实 验表明, $\mathrm{N}: \mathrm{P}>23$ 表现为 $\mathrm{P}$ 限制, $\mathrm{N}: \mathrm{P}<21$ 表现为 $N$ 限 制。Chen等(2011)对中国内蒙古东部大青沟自然保 护区的研究表明, N:P $>14$ 表现为 $\mathrm{P}$ 限制, N:P $<12$ 表 现为N限制。Güsewell等(2003)对草原植物叶片的研 究表明, $N: P>20$ 表现为 $P$ 限制, $N: P<10$ 表现为 $N$ 限 制, 介于两者之间则表明受到 $N 、 P$ 的共同限制作 用。所有研究 $N: P$ 的学者的共识是低的 $\mathrm{N}: \mathrm{P}$ 能明确指 示 $\mathrm{N}$ 的限制作用, 而中、高的 $\mathrm{N}$ : $\mathrm{P}$ 没有明确而恒定的 解释, 目前施肥实验是确定 $\mathrm{N}$ 或 $\mathrm{P}$ 存在限制作用及 
$\mathrm{N}:$ P临界值的最佳办法(朴河春等, 2005; Cui et al., 2010)。近年来, 随着大气N沉降的增加, 陆地生态 系统中有效 $\mathrm{N}$ 增加, 以至于一些原本受 $\mathrm{N}$ 限制的植 被出现“N饱和现象”, 而转变成受P或其他养分元素 的限制(Güsewell, 2004)。但从目前看来, 在N沉降普 遍存在的情况下我国毛竹林仍旧受到 $\mathrm{N}$ 素的限制, 表明适度的 $\mathrm{N}$ 沉降可以促进毛竹的生长, 积累更多 的生物量碳(翁俊等, 2015)。

\section{6 化学计量的空间变化及影响因素}

毛竹叶片的 $\mathrm{N}$ 含量、 N:P随着纬度的增加而增 加, C:N随着纬度增加而降低(表2)。纬度地带性主要 受温度控制, 叶片 $\mathrm{N}$ 含量与温度呈显著负相关关系 (表4), 温度降低限制植物光合 $\mathrm{C}$ 吸收能力, 从而造 成 $\mathrm{C}$ : $\mathrm{N}$ 与温度呈显著正相关关系, 该结果支持 “温度植物生理假说” (TPPH), TPPH认为低温下富 $\mathrm{N}$ 的酶 和富P的RNA的效率降低导致植物生化反应速率的 降低, 而叶片 $\mathrm{N}$ 和 $\mathrm{P}$ 调节植物 $\mathrm{C}$ 需求和利用的速率以 及受 $N$ 和 $P$ 调节过程的动力学均对温度敏感, $N$ 和 $P$ 的增加可以抵消低温造成的生化反应速率降低的效 应，从而 $\mathrm{N}$ 和P浓度表现出随温度升高而单向降低， 这是植物对自然适应的表现。该假说得到了部分实 验上的验证, 研究中国东部南北样带 654 种植物的 $\mathrm{N} 、 \mathrm{P}$ 化学计量发现, 叶片 $\mathrm{N}$ 和P随着纬度升高和年平 均气温的降低其含量极显著地增加(任书杰等, 2007); 研究中国典型草原植物功能群落N、P的生态 化学计量发现, 高寒草地植物的 N、P含量高于温性 草原植物(张文彦等, 2010)。本研究发现毛竹叶片的 $\mathrm{N}: \mathrm{P}$ 随着纬度的升高而增加, 这与 Reich和Oleksyn (2004)研究 $43^{\circ} \mathrm{S}$ 到 $70^{\circ} \mathrm{N}$ 和 $-12.8{ }^{\circ} \mathrm{C}$ 到 $28{ }^{\circ} \mathrm{C}$ 范围内 1280 种陆地植物发现的随着纬度降低和年均气温 的增高, 叶片 N:P升高的结论相反; 而与 Zheng和 Shangguan (2007)研究发现黄土高原 $34^{\circ}-38^{\circ} \mathrm{N}$ 之间 植物叶片 $\mathrm{N}: \mathrm{P}$ 随纬度升高而增大的结论一致。 N:P值 随纬度变化规律可能与研究区域所在位置及尺度大 小有密切关系, 因此基于植物个体水平和物种水平 的研究结果如何向群落尺度推演, 应值得深入探讨 (洪江涛等, 2013)。

毛竹叶片P含量、C:N随经度增加而降低(表3)。 中国的降水从东部沿海到西北内陆逐渐减少, 经度 越高降水量越大, 降水是经度地带性产生的主要影 响因素。本研究中叶片 $\mathrm{N} 、 \mathrm{P}$ 含量与降水量均负相关, 从回归斜率中可以看出, 叶片 $\mathrm{N}$ 含量对降水的响应
比P更敏感(表4)。Han等(2011)对中国植物叶片11种 元素的计量研究发现, 叶片 $\mathrm{N}$ 和P均随经度增大而 降低。本研究中叶片P含量表现出随经度增大而降 低的明显趋势, 而 $\mathrm{N}$ 元素未表现出明显的经度趋势, 可能与温度对 $\mathrm{N}$ 元素的影响程度大于降水有关(表 4)。另外, Han等(2011)经度梯度研究中采用的球面 三角转换方法得到的实际距离 “km”比本文中使用 的“度”更适合于较大经度跨度上的研究，因为不同 纬度上相同的经度跨度, 其代表的实际空间距离并 不完全相同。本文中毛竹叶 $\mathrm{C}: \mathrm{N}$ 值随经度增加而降 低的趋势与大多已有研究结论不一致, 已有研究认 为干旱条件下, 植物通过增加叶片内部非光合组织 $\mathrm{N}$ 的投入和降低植物生长速率, 提高细胞内部渗透 压, 增强对水分的保护, 提高水分的利用效率, 从 而适应干早少雨的环境, 最终导致C:N的降低( $\mathrm{Lu}$ et al., 2009; Planchet et al., 2011; 丁小慧等, 2012)。但 也有研究表明我国植物细根 $\mathrm{N}$ 含量在经度上呈现出 由西向东增加的趋势, 其中东部地区具有较高氮沉 降或许是主要原因(马玉珠等, 2015)。此外, 与已有 大尺度化学计量研究不同之处在于, 本文的研究对 象是同一植物载体, 保证了植物体对元素选择和吸 收上的一致性，从而在地域空间格局表达上更具备 可比性。

毛竹林土壤 $\mathrm{C}: \mathrm{N}$ 随经度增加而增加, $\mathrm{N}$ 含量随经 度增加而降低(表3)。研究发现土壤中的水分能够影 响微生物的分解和 $\mathrm{N}$ 矿化作用, 进而影响土壤中 $\mathrm{N}$ 素的可利用性, 而降水对土壤水分的影响是极其重 要的(Liu et al., 2006)。丁小慧等(2012)发现草原0-10 $\mathrm{cm}$ 土壤SOC、全N受到降水量变化和植物群落元素 总量的影响, 随着经度梯度的升高而增加, 这与本 文的研究结果相反。这是因为呼伦贝尔草原研究区 年降水量仅为 230-360 mm, 年蒸发量为950-1900 $\mathrm{mm}$, 降水对土壤中 $\mathrm{N}$ 元素的淋溶作用几乎可以忽 略。对于毛竹而言, 其适生区雨量充沛, 随着经度梯 度的升高, 降水量显著增加(1055-2 $100 \mathrm{~mm}$ ), 降 水对土壤 $\mathrm{N}$ 元素的淋溶作用大大加强, 导致土壤中 $\mathrm{N}$ 元素的流失, 最终表现为随经度的增加土壤中 $\mathrm{N}$ 含量降低, C:N比增加的趋势。

国内外对于森林调落物研究的关注点大多在调 落物的分解、养分归还以及调落物分解的影响因素 (郭建芬等, 2006), 对于相同树种调落物在经度梯度 上变化规律的研究较少。本研究中毛竹林调落物 $\mathrm{N}$ 
含量随经度增加而降低(表3), 而叶片 $\mathrm{N}$ 含量随经度 梯度的变化与调落物趋势相反, 由此可以推断毛竹 $\mathrm{N}$ 元素的再吸收率随着经度的增加有升高的趋势。 有研究表明, 当土壤某一元素供应相对缺乏的情况 下植物会增强对该元素的再吸收, 呈现较高的再吸 收率, 这一点可以从毛竹土壤 $\mathrm{N}$ 含量随经度增加而 降低得到印证(表3)。可见, 低经度地区毛竹N元素 通过调落物形式归还土壤的比重高于高经度地区, 表明高经度地区 N缺乏的可能性比低经度地区更大, 因此中东部存在的较高氮沉降在一定程度上缓解了 毛竹的N元素限制, 促进了毛竹的快速生长。本研究 中我国毛竹林 $\mathrm{N} 、 \mathrm{P}$ 再吸收率分别为 $39.68 \%$ 和 $54.74 \%$, 而全球水平 $\mathrm{N}$ 和 $\mathrm{P}$ 再吸收率约为 $50 \%$ (Lü \& Han, 2010), 毛竹 N再吸收率明显低于全球水平, 而 $\mathrm{P}$ 再吸收率则略高于全球水平。植物加强对短缺营 养元素的吸收能力是适应养分贫痊环境的一种主要 策略, 当环境中养分供应短缺时, 植物以提高再吸 收率为其养分利用的主导方式, 相反, 当土壤养分 相对充足时, 植物主要以提高养分吸收能力的方式 来适应环境。从这方面来讲, 我国毛竹虽然同时受 到 $\mathrm{N}$ 和 $\mathrm{P}$ 两种元素的限制, 但是生长受到 $\mathrm{P}$ 的限制比 $\mathrm{N}$ 更强烈。Killingbeck (1996) 认为枯落物中 $\mathrm{N}$ 和P分 别超过 $1.00 \%$ 和 $0.08 \%$ 时为非完全吸收, Kozovits等 (2007)发现, 在南非热带P限制的生境下, N为非完 全吸收, $\mathrm{P}$ 为完全吸收。本研究中毛竹调落物 $\mathrm{N}$ 含量 大于 $1.00 \%\left(13.39 \mathrm{mg} \cdot \mathrm{g}^{-1}\right), \mathrm{P}$ 含量约等于 $0.08 \%(0.86$ $\left.\mathrm{mg} \cdot \mathrm{g}^{-1}\right)$, 表明毛竹调落物体内的 $\mathrm{N}$ 没有被完全转移 和再吸收, 而P则被进行了更多的再吸收, 这也进 一步印证了我国毛竹的生长可能受到P元素更多的 限制。 N、P养分的供应能够明显改变植物叶片 $\mathrm{N}$ 、 $\mathrm{P}$ 浓度及化学计量和再吸收率。 $\mathrm{N}$ 添加将提高叶片 $\mathrm{N}$ 浓度, N:P和N再吸收率, 降低叶片 $\mathrm{P}$ 浓度和 $\mathrm{P}$ 再吸收 率; $\mathrm{P}$ 添加将提高叶片 $\mathrm{P}$ 浓度和 $\mathrm{P}$ 再吸收率, 降低 $\mathrm{N}: \mathrm{P}$, 但是对叶片 $\mathrm{N}$ 浓度和 $\mathrm{N}$ 再吸收率无显著影响(陈伏生 等, 2007; 安卓等, 2011)。因此, 随着我国氮沉降和 磷富集等环境问题的日益突出, 不可避免地对植物 生态化学计量特征产生深远的影响, 进而影响到整 个森林生态系统的结构与功能, 因此在后续工作中 应该加强此方面的科学研究。

\section{4 结论}

本文通过对中国各地区毛竹植物体-土壤-调落
物连续体 $\mathrm{C} 、 \mathrm{~N}$ 和P元素含量及其相关数据的收集和 分析, 揭示了毛竹林不同组分 $\mathrm{C} 、 \mathrm{~N} 、 \mathrm{P}$ 生态化学计 量特征及其随经纬度变化的规律和影响因素, 对于 全面了解毛竹林系统计量特征的差异及其内在关联 有重要意义。我国毛竹林生态化学计量特征: 叶片 $C: N$ 为 26.80, C:P为299.60, N:P为 14.40 ; 土壤中 $C: N$ 为 $14.20, \mathrm{C}: \mathrm{P}$ 为 $66.74, \mathrm{~N}: \mathrm{P}$ 为 4.28 ; 调落物 $\mathrm{C}: \mathrm{N}$ 为 $22.53, \mathrm{C}: \mathrm{P}$ 为665.67, $\mathrm{N}: \mathrm{P}$ 为22.55。生态化学计量特征 $\mathrm{C}: \mathrm{N}$ 表现为: 叶片 $>$ 调落物 $>$ 土壤, $\mathrm{C}: \mathrm{P}$ 和 $\mathrm{N}: \mathrm{P}$ 表现为: 调落物 $>$ 叶片 $>$ 土壤, N、P再吸收率分别为 $39.68 \%$ 和 $54.74 \%$, 我国毛竹林生长总体上可能受到 $\mathrm{P}$ 限制或 者 $\mathrm{N}$ 和P元素的双重限制。毛竹林化学计量特征纬度 方向主要受到温度的影响: 毛竹叶片的 $\mathrm{N}$ 含量、 $\mathrm{N}: \mathrm{P}$ 随着纬度的增加而增加, C:N随着纬度增加而降低。 毛竹叶片的 $\mathrm{N}$ 含量随着纬度的增加而增加, 该结果 支持“温度-植物生理假说”, 叶片中 $\mathrm{N}$ 含量与年平均 气温和年降水量均存在明显的线性负相关, 叶片 $\mathrm{N}$ 含量对温度的响应比降水更敏感。经度方向主要受 到降水量的影响: 毛竹叶片 N:P随经度增加而增加, $\mathrm{P}$ 含量、C:N随经度增加而降低; 毛竹林土壤C:N随 经度增加而增加, $\mathrm{N}$ 含量随经度增加而降低; 毛竹林 调落物 $\mathrm{N}$ 含量随经度增加而降低。

基金项目国际竹藤中心基本业务费 (1632013011)、中央级公益性科研院所基本科研业 务费专项(CAFYBB2014QA036)和林业公益性行业 科研专项(201404408)。

\section{参考文献}

Aerts R, Chapin III F (2000). The mineral nutrition of wild plants revisited. Advances in Ecological Research, 30, $1-67$.

Ågren GI (2004). The C:N:P stoichiometry of autotrophsTheory and observations. Ecology Letters, 7, 185-191.

An Z, Niu DC, Wen HY, Yang Y, Zhong HR, Fu H (2011). Effects of $\mathrm{N}$ addition on nutrient resorption efficiency and $\mathrm{C}: \mathrm{N}: \mathrm{P}$ stoichiometric characteristics in Stipa bungeana of steppe grasslands in the Loess Plateau, China. Chinese Journal of Plant Ecology, 35, 801-807. (in Chinese with English abstract) [安卓, 牛的草, 文海燕, 杨益, 张洪荣, 傅华 (2011). 氮素添加对黄土高原典型草原长芒草氮 磷重吸收率及 $\mathrm{C}: \mathrm{N}: \mathrm{P}$ 化学计量特征的影响. 植物生态学 报, 35, 801-807.]

Bai JH, Deng W, Zhu YM, Luan ZQ, Zhang YX (2003). Spatial distribution characteristics and ecological effects of carbon and nitrogen of soil in Huolin River catchment wetland. Chinese Journal of Applied Ecology, 14, 1494-1498. (in 
Chinese with English abstract) [白军红, 邓伟, 朱颜明, 少兆擎, 张玉霞 (2003). 霍林河流域湿地土壤碳氮空间 分布特征及生态效应. 应用生态学报, 14, 1494-1498.]

Cao J, Zhang YL, Liu YH (2002). Changes in forest biomass carbon storage in Hainan Island over the last 20 years. Geographical Research, 21, 551-560. (in Chinese with English abstract) [曹军, 张镱锂, 刘燕华 (2002). 近20 年海南岛森林生态系统碳储量变化. 地理研究, 21 , 551-560.]

Chen FS, Hu XF, Ge G (2007). Leaf N:P stoichiometry and nutrient resorption efficiency of Ophiopogon japonicus in Nanchang City. Acta Prataculturae Sinica, 16(4), 47-54. (in Chinese with English abstract) [陈伏生, 胡小飞, 葛刚 (2007). 城市地被植物麦冬叶片氮磷化学计量比和养分 再吸收效率. 草业学报 16(4), 47-54.]

Chen FS, Niklas KJ, Zeng DH (2011). Important foliar traits depend on species-grouping: Analysis of a remnant temperate forest at the Keerqin sandy lands, China. Plant and Soil, 340, 337-345.

Cleveland CC, Liptzin D (2007). C: N: P stoichiometry in soil: Is there a "Redfield ratio" for the microbial biomass? Biogeochemistry, 85, 235-252.

Cui Q, Lü XT, Wang QB, Han XG (2010). Nitrogen fertilization and fire act independently on foliar stoichiometry in a temperate steppe. Plant and Soil, 334, 209-219.

Dijkstra FA, Pendall E, Morgan JA, Blumenthal DM, Carrillo Y, Le Cain DR, Follett RF, Williams DG (2012). Climate change alters stoichiometry of phosphorus and nitrogen in a semiarid grassland. New Phytologist, 196, 807-815.

Ding XH, Luo SZ, Liu JW, Li K, Liu GH (2012). Longitude gradient changes on plant community and soil stoichiometry characteristics of grassland in Hulunbeir. Acta Ecologica Sinica, 32, 3467-3476. (in Chinese with English abstract) [丁小慧, 罗淑政, 刘金嵬, 李魁, 刘国华 (2012). 呼伦贝尔草地植物群落与土壤化学计量学征沿 经度梯度变化. 生态学报, 32, 3467-3476.]

Du MY, Fan SH, Liu GL, Qi LH, Guo BH, Tang XL, Xiao FM (2013). Effects of land use change on soil labile organic carbon in central Jiangxi of China. Chinese Journal of Applied Ecology, 24, 2897-2904. (in Chinese with English abstract) [杜满义, 范少辉, 刘广路, 漆良华, 郭宝华, 唐晓鹿, 肖复明 (2013). 土地利用方式转变对赣中地区 土壤活性有机碳的影响. 应用生态学报, 24, 28972904.]

Elser JJ, Acharya K, Kyle M, Cotner J, Makino W, Markow T, Watts T, Hobbie S, Fagan W, Schade J (2003). Growth rate-stoichiometry couplings in diverse biota. Ecology Letters, 6, 936-943.

Elser JJ, Fagan WF, Denno RF, Dobberfuhl DR, Folarin A, Huberty A, Interlandi S, Kilham SS, McCauley E, Schulz
KL (2000a). Nutritional constraints in terrestrial and freshwater food webs. Nature, 408, 578-580.

Elser JJ, Sterner RW, Gorokhova E, Fagan WF, Markow TA, Cotner JB, Harrison JF, Hobbie SE, Odell GM, Weider LW (2000b). Biological stoichiometry from genes to ecosystems. Ecology Letters, 3, 540-550.

Fan SH, Xiao FM, Wang SL, Sun WH, Yu XJ, Shen ZQ (2009). Fine root biomass and turnover in moso bamboo plantation in Huitong forest station, Hunan Province. Scientia Silvae Sinicae, 45(7), 1-6. (in Chinese with English abstract) [范少辉, 肖复明, 汪思龙, 苏文会, 于 小军, 申正其 (2009). 毛竹林细根生物量及其周转. 林 业科学, 45(7), 1-6.]

Fang JY, Piao SL, Zhao SQ (2001). The carbon sink: The role of the middle and high latitudes terrestrial ecosystem in the northern Hemisphere. Acta Phytoecologica Sinica, 25, 594-602. (in Chinese with English abstract) [方精云, 朴 世龙, 赵淑清 (2001). $\mathrm{CO}_{2}$ 失汇与北半球中高纬度陆地 生态系统的碳汇. 植物生态学报, 25, 594-602.]

Gu DX, Chen SL, Huang YQ (2011). Effects of soil nitrogen and phosphonium on leaf nitrogen and phosphonium stoichiometric characteristics and chlorophyll content of Oligostachyum lubricum. Chinese Journal of Plant Ecology, 35, 1219-1225. (in Chinese with English abstract) [顾大 形, 陈双林, 黄玉清 (2011). 土壤氮磷对四季竹叶片氮 磷化学计量特征和叶绿素含量的影响. 植物生态学报, $35,1219-1225$.]

Guo BH (2014). Ecological Stoichiometry Characteristics of Carbon, Nitrogen and Phosphorus in Phyllostachys pubescens Forest of Different Productivity Levels. PhD dissertation, Chinese Academy of Forestry, Beijing. (in Chinese with English abstract) [郭宝华 (2014). 不同生 产力水平毛竹林碳氮磷生态化学计量特征研究. 博士 学位论文, 中国林业科学研究, 北京.]

Guo BH, Liu GL, Fan SH, Du MY, Sun WH (2014). Distribution patterns and stoichiometry characteristics of C, N, P in Phyllostachys edulis forests of different productivity levels. Scientia Silvae Sinicae, 50(6), 1-9. (in Chinese with English abstract) [郭宝华, 刘广路, 范少辉, 杜满义, 苏 文会 (2014). 不同生产力水平毛竹林碳氮磷的分布格 局和计量特征. 林业科学, 50(6), 1-9.]

Guo JF, Yang YS, Chen GS, Lin P, Xie JZ (2006). A review on litter decomposition in forest ecosystem. Scientia Silvae Sinicae, 42(4), 93-100 . (in Chinese with English abstract) [郭建芬, 杨玉盛, 陈光水, 林鹏, 谢锦忠 (2006). 森林 调落物分解研究进展. 林业科学, 42(4), 93-100.]

Güsewell S, Koerselman W, Rspagen JTA (2003). Biomass $\mathrm{N}: \mathrm{P}$ ratios as indicators of nutrient limitation of plant populations in wetlands. Ecological Applications, 13, 372-384. 
Güsewell S (2004). N:P ratios in terrestrial plants: Variation and functional significance. New Phytologist, 164, 243-266.

Han WX, Fang JY, Guo DL, Zhang Y (2005). Leaf nitrogen and phosphorus stoichiometry across 753 terrestrial plant species in China. New Phytologist, 168, 377-385.

Han WX, Fang JY, Peter BR, Woodwar FI, Wang ZH (2011). Biogeography and variability of eleven mineral elements in plant leaves across gradients of climate, soil and plant functional type in China. Ecology Letters, 14, 788-796.

Han WX, Tang LY, Chen YH, Fang JY (2013). Relationship between the relative limitation and resorption efficiency of nitrogen vs phosphorus in woody plants. PLOS ONE, 8, e83366. doi: 10.1371/journal.pone.0083366.

Han WX, Wu Y, Tang LY, Chen YH, Li LP, He JS, Fang JY (2009). Leaf carbon, nitrogen and phosphorus stoichiometry across plant species in Beijing and its periphery. Acta Scientiarum Naturalium Universitatis Pekinensis, 45, 855-860. (in Chinese with English abstract) [ [韩文轩, 吴 渏, 汤璐瑛, 陈雅涵, 李利平, 贺金生, 方精云 (2009). 北京及周边地区植物叶的碳氮磷元素计量特征. 北京 大学学报(自然科学版), 45, 855-860.]

He JS, Han XG (2010). Ecological stoichiometry: Searching for unifying principles from individuals to ecosystems. Chinese Journal of Plant Ecology, 34, 2-6. (in Chinese with English abstract) [贺金生, 韩兴国 (2010). 生态化学计 量学: 探索从个体到生态系统的统一化理论. 植物生态 学报, 34, 2-6.]

Hong JT, Wu JB, Wang XD (2013). Effects of global climate change on the $\mathrm{C}, \mathrm{N}$, and $\mathrm{P}$ stoichiometry of terrestrial plants. Chinese Journal of Applied Ecology, 24, 26582665. (in Chinese with English abstract) [洪江涛, 吴建波, 王小丹 (2013). 全球气候变化对陆地植物碳氮磷生态 化学计量学特征的影响. 应用生态学报, 24, 26582665.]

Jackson RB, Mooney H, Schulze ED (1997). A global budget for fine root biomass, surface area, and nutrient contents. Proceedings of the National Academy of Sciences of the United States of America, 94, 7362-7366.

Jiang ZH (2002). Bamboo and Rattan in the World. Liaoning Science and Technology Press, Shenyang. (in Chinese) [江 泽慧 (2002). 世界竹藤. 辽宁科学技术出版社, 沈阳.]

Killingbeck KT (1996). Nutrients in senesced leaves: Keys to the search for potential resorption and resorption proficiency. Ecology, 77, 1716-1727.

Koerselman W, Meuleman AF (1996). The vegetation N:P ratio: A new tool to detect the nature of nutrient limitation. Journal of Applied Ecology, 33, 1441-1450.

Kozovits AR, Bustamante MMC, Garofalo CR, Bucci S, Franco AC, Goldstein G, Meinzer FC (2007). Nutrient resorption and patterns of litter production and decomposition in a neotropical savanna. Functional Ecology, 21, 1034-1043.

Ladanai S, Ågren GI, Olsson BA (2010). Relationships between tree and soil properties in Picea abies and Pinus sylvestris forests in Sweden. Ecosystems, 13, 302-316.

Li CJ, Lei JQ, Xu XW, Tang QL, Gao P, Wang YD (2013). The stoichiometric characteristics of C, N, P for artificial plants and soil in the hinterland of Taklimakan Desert. Acta Ecologica Sinica, 33, 5760-5767. (in Chinese with English abstract) [李从娟, 雷加强, 徐新文, 唐清亮, 高 培, 王永东 (2013). 塔克拉玛干沙漠腹地人工植被及土 壤CNP的化学计量特征. 生态学报, 33, 5760-5767.]

Li MR, Sha LQ (2005). Soil nitrogen mineralization under different land use patterns in Xishuangbanna. Chinese Journal of Applied Ecology, 16, 54-58. (in Chinese with English abstract) [李明锐, 沙丽清 (2005). 西双版纳不 同土地利用方式下土壤氮矿化作用研究. 应用生态学 报, 16, 54-58.]

Lin ZB, Yan PY, Yang ZJ, Wan XH, Chen GS (2011). Leaf nitrogen and phosphorus stoichiometry across 101 woody species in Wanmulin, Fujian Province. Journal of Subtropical Resource and Environment, 6(1), 32-38. (in Chinese with English abstract) [林志斌, 严平勇, 杨智杰, 万晓华, 陈光水 (2011). 福建万木林 101 种常见木本植 物叶片N, P化学计量学特征. 亚热带资源与环境学报, 6(1), 32-38.]

Liu CJ, Berg B, Kutsch W, Westman C, Ilvesnieme H, Shen XH, Shen GR, Chen XB (2006). Leaf litter nitrogen concentration as related to climatic factors in Eurasian forests. Global Ecology and Biogeography, 15, 438-444.

Liu GH, Fu BJ, Fang JY (2000). Carbon dynamics of Chinese forests and its contribution to global carbon balance. Acta Ecologica Sinica, 20, 733-740. (in Chinese with English abstract) [刘国华, 傅伯杰, 方精云 (2000). 中国森林碳 动态及其对全球碳平衡的贡献. 生态学报, 20,733740.]

Liu GL (2009). Long Term Productivity of Bamboo Forest. $\mathrm{PhD}$ dissertation, Chinese Academy of Forestry, Beijing. (in Chinese with English abstract) [刘广路 (2009). 毛竹 林长期生产力保持机制研究. 博士学位论文, 中国林业 科学研究院, 北京.]

Liu WD, Su JR, Li SF, Zhang ZJ, Li ZW (2010). Stoichiometry study of $\mathrm{C}, \mathrm{N}$ and $\mathrm{P}$ in plant and soil at different successional stages of monsoon evergreen broad-leaved forest in Pu'er, Yunnan Province. Acta Ecologica Sinica, 30, 6581-6590. (in Chinese with English abstract) [刘万 德, 苏建荣, 李帅锋, 张志钧, 李忠文 (2010). 云南普 洱季风常绿阔叶林演替系列植物和土壤 $\mathrm{C}, \mathrm{N}, \mathrm{P}$ 化学计 量特征. 生态学报, 30, 6581-6590.]

Liu WJ, Chen SY, Hu FZ, Sa N (2012). Distributions pattern of 
phosphorus, potassium and influencing factors in the upstream of Shule river basin. Acta Ecologica Sinica, 32, 5429-5437. (in Chinese with English abstract) [刘文杰, 陈生云, 胡风祖, 莎娜 (2012). 疏勒河上游土壤磷和钾 的分布及其影响因素. 生态学报, 32, 5429-5437.]

Liu XZ, Zhou GY, Zhang DQ, Liu SZ, Chu GW, Yan JH (2010). N and P stoichiometry of plant and soil in lower subtropical forest successional series in southern China. Chinese Journal of Plant Ecology, 34, 64-71. (in Chinese with English abstract) [刘兴诏, 周国逸, 张德强, 刘世 忠, 褚国伟, 闰俊华 (2010). 南亚热带森林不同演替阶 段植物与土壤中 $\mathrm{N}, \mathrm{P}$ 的化学计量特征. 植物生态学报, 34, 64-71.]

Liu YJ, Li Q, Ma MD (2010). Comparison of soil nutrient storage of forest vegetation type in northwest of Sichuan Province. Journal of Soil and Water Conservation, 24(5), 146-152. (in Chinese with English abstract) [刘跃建, 李 强, 马明东 (2010). 四川西北部主要森林植被类型土壤 养分库比较研究. 水土保持学报, 24(5), 146-152.]

Lü XT, Han XG (2010). Nutrient resorption responses to water and nitrogen amendment in semi-arid grassland of Inner Mongolia, China. Plant \& Soil, 327, 481-491.

Lü XT, Kong DL, Pan QM, Simmons ME, Han XG (2012). Nitrogen and water availability interact to affect leaf stoichiometry in a semi-arid grassland. Oecologia, 168, 301-310

Lu YW, Duan BL, Zhang XL, Korpelainen H, Li CY (2009). Differences in growth and physiological traits of Populus cathayana populations as affected by enhanced UV-B radiation and exogenous ABA. Environmental and Experimental Botany, 66, 100-109.

Ma YZ, Zhong QL, Jin BJ, Lu HD, Guo BQ, Zheng Y, Li M, Cheng DL (2015). Spatial changes and influencing factors of fine root carbon, nitrogen and phosphorus stoichiometry of plants in China. Chinese Journal of Plant Ecology, 39, 159-166. (in Chinese with English abstract) [马玉珠, 钟 全林, 靳冰洁, 卢宏典, 郭炳桥, 郑媛, 李曼, 程栋梁 (2015). 中国植物细根碳、氮、磷化学计量学的空间变 化及其影响因子. 植物生态学报, 39, 159-166.]

McGroddy ME, Daufresne T, Hedin LO (2004). Scaling of $\mathrm{C}: \mathrm{N}: \mathrm{P}$ stoichiometry in forests worldwide: Implications of terrestrial Redfield-type ratios. Ecology, 85, 2390-2401.

Mclauchlan KK, Hobbie SE, Post WM (2006). Conversion from agriculture to grassland builds soil organic matter on decadal timescales. Ecological Applications, 16, 143-153.

Michaels AF (2003). The ratios of life. Science, 300, 906-907.

Mooshammer M, Wanek W, Schnecker J, Wild B, Leitner S, Hofhansl F, Blöchl A, Hämmerle I, Frank AH, Fuchslueger L, Keiblinger KM, Zechmeister-Boltenstern S, Richter A (2012). Stoichiometric controls of nitrogen and phosphorus cycling in decomposing beech leaf litter.
Ecology, 93, 770-782.

Niu DC, Li Q, Jiang SG, Chang PJ, Fu H (2013). Seasonal variations of leaf C:N:P stoichiometry of six shrubs in desert of China's Alxa Plateau. Chinese Journal of Plant Ecology, 37, 317-325. (in Chinese with English abstract) [牛得草, 李茜, 江世高, 常佩静, 傅华 (2013). 阿拉善 荒漠区6种主要灌木植物叶片 C:N:P化学计量比的季节 变化. 植物生态学报, 37, 317-325.]

Piao HC, Liu CQ, Zhu SF, Zhu JM (2005). Variations of $\mathrm{C}_{4}$ and $\mathrm{C}_{3}$ plant N:P ratios influenced by nutrient stoichiometry in limestone and sandstone area of Guizhou. Quaternary Sciences, 25, 552-560. (in Chinese with English abstract) [朴河春, 刘丛强, 朱书法, 朱建明 (2005). 贵州石灰岩 和砂岩地区 $\mathrm{C}_{4}$ 和 $\mathrm{C}_{3}$ 植物营养元素的化学计量对 $N / P$ 比值 波动的影响. 第四纪研究, 25, 552-560.]

Planchet E, Rannou O, Rlcoult C, Boutet-Mercey S, MalaGrondard A, Limaml AM (2011). Nitrogen metabolism responses to water deficit act through both abscisic acid (ABA)-dependent and independent pathways in Medicago truncatula during post-germination. Journal of Experimental Botany, 62, 605-615.

Reich PB, Oleksyn J (2004). Global patterns of plant leaf N and $\mathrm{P}$ in relation to temperature and latitude. Proceedings of the National Academy of Sciences of the United States of America, 101, 11001-11006.

Ren SJ, Yu GR, Jiang CM, Fang HJ, Sun XM (2012). Stoichiometric characteristics of leaf carbon, nitrogen, and phosphorus of 102 dominant species in forest ecosystems along the North South Transect of East China. Chinese Journal of Applied Ecology, 23, 581-586. (in Chinese with English abstract) [任书杰，于贵瑞，姜春明，方华军，孙晓敏 (2012). 中国东部南北样带森林生态系统102个优势种 叶片碳氮磷化学计量学统计特征. 应用生态学报, 23 , 581-586.]

Ren SJ, Yu GR, Tao B, Wang SQ (2007). Leaf nitrogen and phosphorus stoichiometry across 654 terrestrial plant species in NSTEC. Envirmental Science, 28, 2665-2673. (in Chinese with English abstract) [任书杰, 于贵瑞, 陶 波，王绍强 (2007). 中国东部南北样带654种植物叶片 氮和磷的化学计量学特征研究. 环境科学, 28, 26652673.]

Song YT, Zhou DW, Li Q, Wang P, Huang YX (2012). Leaf nitrogen and phosphorus stoichiometry in 80 herbaceous plant species of Songnen grassland in Northeast China. Chinese Journal of Plant Ecology, 36, 222-230. (in Chinese with English abstract) [宋彦涛, 周道玮, 李强, 王平, 黄迎新 (2012). 松嫩草地80种草本植物叶片氮磷 化学计量特征. 植物生态学报, 36, 222-230.]

State Forestry Administration (2014). China Forest Resources Report. China Forestry Publishing House, Beijing. (in Chinese) [国家林业局 (2014). 中国森林资源报告. 中 
国林业出版社，北京.]

Tang GY, Li K, Sun YY, Zhang CH (2010). Soil labile organic carbon contents and their allocation characteristics under different land uses at dry-hot valley. Enviromental Science, 31, 1365-1371. (in Chinese with English abstract) [唐国勇, 李昆, 孙永玉，张春华 (2010). 干热河谷不同 利用方式下土壤活性有机碳含量及其分配特征. 环境 科学, 31, 1365-1371.]

Tessier JT, Raynal DJ (2003). Use of nitrogen to phosphorus ratios in plant tissue as an indicator of nutrient limitation and nitrogen saturation. Journal of Applied Ecology, 40, 523-534.

Tian HQ, Chen GS, Zhang C, Melillo JM, Hall CA (2010). Pattern and variation of C:N:P ratios in China's soils: A synthesis of observational data. Biogeochemistry, 98, 139-151.

Vitousek PM (2003). Stoichiometry and flexibility in the Hawaiian model system. In: Melillo JM, Field CB, Moldan B eds. Interactions of the Major Biogeochemical Cycles: Global Change and Human Impacts. Island Press, Washington. 117-133

Wang JY, Wang SQ, Li RL, Yan JH, Sha LQ, Han SJ (2011). $\mathrm{C}: \mathrm{N}: \mathrm{P}$ stoichiometric characteristics of four forest types' dominant tree species in China. Chinese Journal of Plant Ecology, 35, 587-595. (in Chinese with English abstract) [王晶苑, 王绍强, 李㧅兰, 间俊华, 沙丽清, 韩士杰 (2011). 中国四种森林类型主要优势植物的 C:N:P化学 计量学特征. 植物生态学报, 35, 587-595.]

Wang WQ, Xu LL, Zeng CS, Tong C, Zhang LH (2011). Carbon, nitrogen and phosphorus ecological stoichiometric ratios among live plant-litter-soil systems in estuarine wetland. Acta Ecologica Sinica, 31, 7119-7124. (in Chinese with English abstract) [王维奇, 徐玲琳, 曾从盛, 圭川, 张林海 (2011). 河口湿地植物活体-枯落物-土壤的碳氮 磷生态化学计量特征. 生态学报, 2011, 7119-7124.]

Wang XX, Liu L, Zhang J, Wang YK, Wen GS, Gao RF, Gao Y, Zhang RM (2012). Changes of photosynthetic pigment and photosynthetic enzyme activity in stems of Phyllostachys pubescens during rapid growth stage after shooting. Chinese Journal of Plant Ecology, 36, 456-462. (in Chinese with English abstract) [王星星, 刘琳, 张洁, 王玉魁, 温国胜, 高荣孚, 高岩, 张汝民 (2012). 毛竹 出笋后快速生长期内茎秆中光合色素和光合酶活性的 变化. 植物生态学报, 36, 456-462.]

Weng J, Gu HH, Wang ZH, Zhao MS, Song XZ (2015). The effects of nitrogen deposition on ecological stoichiometry of leaf of Moso bamboo with extensive management. Ecological Science, 34(2), 63-70. (in Chinese with English abstract) [翁俊, 顾鸿昊, 王志坤, 赵明水, 宋新 章 (2015). 氮沉降对毛竹叶片生态化学计量特征的影 响. 生态科学, 34(2), 63-70.]
Wright IJ, Reich PB, Westoby M, Ackerly DD, Baruch Z, Bongers F, Cavender-Bares J, Chapin T, Cornelissen JH, Diemer M (2004). The worldwide leaf economics spectrum. Nature, 428, 821-827.

Wu JS, Jiang PK, Wang ZL (2008). The effects of Phyllostachys pubescens expansion on soil fertility in national nature reserve of mount Tianmu. Acta Agriculturae Universitatis Jiangxiensis, 30, 689-692. (in Chinese with English abstract) [吴家森, 姜培坤, 王祖良 (2008). 天 目山国家级自然保护区毛竹扩张对林地土壤肥力的影 响. 江西农业大学学报, 30, 689-692.]

Wu TG, Wu M, Liu L, Xiao JH (2010). Seasonal variations of leaf nitrogen and phosphorus stoichiometry of three herbaceous species in Hangzhou Bay coastal wetlands, China. Chinese Journal of Plant Ecology, 34, 23-28. (in Chinese with English abstract) [吴统贵，吴明，刘丽，萧江华 (2010). 杭州湾滨海湿地3种草本植物叶片N, P化学计 量学的季节变化. 植物生态学报, 34, 23-28.]

Xu WQ, Chen X, Luo GP, Wang T, Lin Q (2009). Soil orgaic carbon storage and its spatial distribution characteristic in the Sangong River watershed of arid region. Journal of Natural Resources, 24, 1740-1747. (in Chinese with English abstract) [许文强, 陈䂀, 罗格平, 王涛, 萄卿 (2009). 干旱区三工河流域土壤有机碳储量及空间分布 特征. 自然资源学报, 24, 1740-1747. ]

Yan ER, Wang XH, Guo M, Zhong Q, Zhou W (2010). C:N:P stoichiometry across evergreen broad-leaved forests, evergreen coniferous forests and deciduous broad-leaved forests in the Tiantong region, Zhejiang Province, eastern China. Chinese Journal of Plant Ecology, 34, 48-57. (in Chinese with English abstract) [阎恩荣，王希华，郭明， 仲强, 周武 (2010). 浙江天童常绿阔叶林, 常绿针叶林 与落叶阔叶林的 $\mathrm{C}: \mathrm{N}: \mathrm{P}$ 化学计量特征. 植物生态学报, 34, 48-57.]

Yan K, Fu DG, He F, Duan CQ (2011). Leaf nutrient stoichiometry of plants in the phosphorus-enriched soils of the Lake Dianchi watershed, southwestern China. Chinese Journal of Plant Ecology, 35, 353-361. (in Chinese with English abstract) [阎凯，付登高，何峰，段昌群 (2011). 滇池流域富磷区不同土壤磷水平下植物叶片的养分化 学计量特征. 植物生态学报, 35, 353-361.]

Yang JJ, Zhang XR, Ma LS, Chen YN, Dang YH, An SS (2014). Ecological stoichiometric relationships between components of Robinia pseudoacacia forest in Loess Plateau. Acta Pedologica Sinica, 51, 133-142. (in Chinese with English abstract) [杨佳佳, 张向茹，马露莎，陈亚 南, 党延辉, 安韶山 (2014). 黄土高原刺槐林不同组分 生态化学计量关系研究. 土壤学报, 51, 133-142.]

Zeng DP, Jiang LL, Zeng CS, Wang WQ, Wang C (2013). Reviews on the ecological stoichiometry characteristics and its applications. Acta Ecologica Sinica, 33, 5484- 
5492. (in Chinese with English abstract) [曾冬萍, 蒋利玲, 曾从盛, 王维奇, 王纯 (2013). 生态化学计量学特征及 其应用研究进展. 生态学报, 33, 5484-5492.]

Zeng ZX, Wang KL, Liu XL, Zeng FP, Song TQ, Peng WX, Zhang H, Du H (2015). Stoichiometric characteristics of plants, litter and soils in karst plant communities of Northwest Guangxi. Chinese Journal of Plant Ecology, 39, 682-693. (in Chinese with English abstract) [曾昭霞, 王 克林, 刘孝利, 曾馥平, 宋同清, 彭晚霞, 张浩, 杜虎 (2015). 桂西北喀斯特森林植物-调落物-土壤生态化学 计量特征. 植物生态学报, 39, 682-693.]

Zhang LX, Bai YF, Han XG (2003). Application of N:P stoichiometry to ecology studies. Acta Botanica Sinica, 45, 1009-1018.

Zhang LX, Bai YF, Han XG (2004). Differential responses of $\mathrm{N}: \mathrm{P}$ stoichiometry of Leymus chinensis and Carex korshinskyi to $\mathrm{N}$ additions in a steppe ecosystem in Nei Mongol. Acta Botanica Sinica, 46, 259-270.

Zhang WY, Fan JW, Zhong HP, Hu ZM, Song LL, Wang N (2010). The nitrogen: phosphorous stoichiometry of different plant functional groups for dominant species of typical steppes in China. Acta Agrestia Sinica, 18, 503- 509. (in Chinese with English abstract) [张文彦，紮江文，钟华 平，胡中民，宋璐璐，王宁 (2010). 中国典型草原优势 植物功能群氮磷化学计量学特征研究. 草地学报, 18 , 503-509.]

Zhang XR, Ma LS, Chen YN, Yang JJ, An SS (2013). Ecological stoichiometry characteristics of Robinia Pseudoacacia forest soil in different latitudes of Loess Plateau. Acta Pedologica Sinica, 50, 818-825. (in Chinese with English abstract) [张向茹, 马露莎, 陈亚南, 杨佳
佳, 安韶山 (2013). 黄土高原不同纬度下刺槐林土壤生 态化学计量学特征研究. 土壤学报, 50, 818-825.]

Zhao HY, Li YL, Wang XY, Mao W, Zhao XY, Zhang TH (2010). Variations in leaf traits of 52 plants in Horqin sand land. Journal of Desert Research, 30, 1292-1298. (in Chinese with English abstract) [赵红洋, 李玉霖, 王新源, 毛伟, 赵学勇, 张铜会 (2010). 科尔沁沙地52种植物叶 片性状变异特征研究. 中国沙漠, 30, 1292-1298.]

Zhao MS, Zhang GL, Li DC, Zhao YG (2013). Variability of soil organic matter and its main factors in Jiangsu Province. Acta Ecologica Sinica, 33, 5058-5066. (in Chinese with English abstract) [赵明松, 张甘霖, 李德成, 赵玉国 (2013). 江苏省土壤有机质变异及其主要影响因素. 生 态学报, 33, 5058-5066.]

Zhao Q, Zeng DH (2005). Phosphorus cycling in terrestrial ecosystems and its contrilling factors. Acta Phytoecologica Sinica, 29, 153-163. (in Chinese with English abstract) [赵 琼, 曾德慧 (2005). 陆地生态系统磷素循环及其影响因 素. 植物生态学报, 29, 153-163.]

Zheng SX, Shangguan ZP (2006). The distribution pattern of leaf nutuient composition in the Loess Plateau. Progress in Natural Science, 16, 965-973. (in Chinese with English abstract) [郑淑霞，上官周平 (2006). 黄土高原地区植 物叶片养分组成的空间分布格局. 自然科学进展, 16 , 965-973.]

Zheng SX, Shangguan ZP (2007). Spatial patterns of leaf nutrient traits of the plants in the Loess Plateau of China. Trees, 21, 357-370.

责任编委: 韩文轩 责任编辑: 李 敏 